\title{
New records of Storthyngura (Crustacea, Isopoda, Asellota) from the Antarctic deep sea with descriptions of two new species
}

\author{
Marina Malyutina $^{1}$ \& Angelika Brandt ${ }^{2}$
}

With 20 figures and 2 tables

\begin{abstract}
Storthyngura longispina sp. nov. and $S$. antarctica sp. nov. are described from the deep sea of the West-Atlantic part of Antarctica. The new species are most similar to $S$. elegans Vanhöffen, 1914 and $S$. parka Malyutina \& Wägele, 2001, forming a group of closely related species. New data on three known species from the region: S. elegans Vanhöffen, 1914, S. kussakini Brandt \& Malyutina, 2002 and S. phyllosoma (Just, 2001) comb. nov., and redescription of S. snanoi Menzies, 1962 from the northwestern Atlantic are also presented. The genus Storthyngura is re-evaluated, and the recently described genus Platyprotus Just, 2001 is reduced to a junior synonym of Storthyngura.
\end{abstract}

Key words: Deep sea, Antarctica, taxonomy, Munnopsididae, Storthyngura, new species.

\section{Introduction}

The heterogeneity of the large genus Storthyngura has been mentioned by many authors (Wolff 1962, George \& Menzies 1968, Birstein 1969, Wilson et al. 1989, Malyutina 1999), but since most of the descriptions of the species were not enough informative, any detailed taxonomic assessment of diversity within the genus was difficult. Recent and more detailed descriptions have been given for redescribing the type species of Storthyngura, S. elegans Vanhöffen, 1914 (Malyutina \& Wägele 2000), S. parka Malyutina \& Wägele, 2000 and. S. kussakini Brandt $\&$ Malyutina, 2002. The new data from those species and data from some other species of Storthyngura provided the basis for redefining Storthyngura (Malyutina, 2003) with the establishment of three new genera. Nine species are retained in Storthyngura, namely S. elegans, S. parka, S. kussakini, S. intermedia (Beddard, 1885), S. magnispinis (Richardson, 1908), S. octospinosalis Menzies \& George, 1972, S. snanoi Menzies, 1962, S. truncata (Richardson, 1908), and S. vemae Menzies, 1962. The diagnosis and description of the redefined genus Storthyngura was based mainly on the data from S. elegans,
S. parka and S. kussakini, because all other species were unavailable for study and their original descriptions do not contain enough information.

Two Antarctic expeditions (ANT XV-3 in 1998 and ANDEEP in 2002) off the South Shetland Islands and in the Weddell Sea yielded a small collection of Storthyngura from depths between $938-3640 \mathrm{~m}$. The new material presented here includes two new species, S. longispina sp. nov. and $S$. antarctica sp.nov. and three known species S. elegans, S. kussakini and S. phyllosoma (Just, 2001). For comparison the holotype of $S$. snanoi was also examined. The new data allowed to corroborate and specify the Storthyngura diagnosis and to reappraise the genus. The recently described genus Platyprotus Just, 2001 was consequently recognised as a junior synonym of Storthyngura.

\section{Methods}

Specimens were collected during the expeditions ANT XV-3 in February 1998 in the Weddell Sea and ANT XIX-3, ANDEEP I (Antarctic benthic DEEP-sea biodiversity: colonisation history and recent community patterns) in February 2002 onboard the RV Polarstern in the Antarctic deep sea off the South Shetland Is. and in the Weddell Sea. Collections were made means of an epibenthic sledge (Brandt \& Barthel

1 Institute of Marine Biology, FEB RAS, Palchevskogo 17, 690041, Vladivostok, Russia.

E-Mail: inmarbio@mail.primorye.ru

${ }^{2}$ Zoologisches Institut und Zoologisches Museum, Martin-Luther-King-Platz 3, 20146 Hamburg, Germany.

E-Mail: Abrandt@zoologie.uni-hamburg

Received October 2002, accepted March 2003 
1995). The material was fixed in precooled $80 \%$ ethanol. In the laboratory, the material was sorted and determined using a Wild M5 dissecting microscope and illustrated using a Leitz Dialux microscope, equipped with a camera lucida.

Terminology and measurements were made following Wilson (1989). Total body length was measured medially from the anterior edge of the head to the posterior tip of the pleotelson. Length of segments was measured medially or laterally from the anterior margin without spine to the posterior margin. Spines were measured from the tip to the basis along the anterolateral margin. If an animal could be completely straightened, we used the dorsal view for the measuring, like for measuring any width. However, when body was curled, the lengths of its segments and dorsal spines were measured in lateral view.

Scale bars of dorsal views are $1 \mathrm{~mm}$, those of appendages $0.5 \mathrm{~mm}$ unless otherwise noted in figure captions.

The types of the new species are deposited in the Zoological Museum, Hamburg.

The following abbreviations are used in the text and figures: $\mathrm{ZMH}=$ Zoological Museum, Hamburg, AMNH = American Museum of Natural History; $E=$ epinet, $S=$ supranet; $\mathrm{A} 1=$ antenna $1, \mathrm{~A} 2=$ antenna $2, \mathrm{~F}=$ female, $\mathrm{Hy}=$ hypopharynx, $1 \mathrm{Md}=$ left mandible, $\mathrm{rMd}=$ right mandible, $\mathrm{M}=$ male, $\mathrm{Mx} 1=$ maxilla $1, \mathrm{Mx} 2=$ maxilla $2, \mathrm{Mxp}=$ maxilliped, $\mathrm{P} 1-7$ $=$ pereopod $1-7$, Plp $1-5=$ pleopod $1-5$, Urp $=$ uropod

\section{Taxonomy}

\section{Munnopsididae Sars, 1869}

\section{Storthyngurinae Kussakin, 2003}

\section{Storthyngura Vanhöffen, 1914}

Storthyngura Vanhöffen, 1914: 583; Hansen 1916: 132; Birstein 1957: 962; Menzies 1962: 145; Wolff 1962: 118; George \& Menzies 1968: 277-279; Kussakin in press; Malyutina 2003 (new combination).

Platyprotus Just, 2001: 336 (new synonymy)

Type species. S. elegans Vanhöffen, 1914

Species included. See Table 1.

Diagnosis. Body relatively small $(2-10 \mathrm{~mm})$, flattened. Head without dorsal spines. Pleotelson terminal projection rather broad, about one third as wide as pleotelson, not pointed apically; margin between posterolateral and terminal projections with rounded notches for uropods; preanal ridge weakly prominent, rounded. Antenna 1 article 1 with medial spine; article 2 narrow, without distomedial process. Pereopods 3 and 4 insignificantly longer than pereopod 2, with stout carpus, bearing several spine-like setae on distal third of ventral margin. The other characters of Storthyngura are listed in Table 2, most representatives are presented in Fig. 20 (compare also with diagnosis and description of the genus in Malyutina, in press).

Remarks. Just (2001) had erected the new monotypic genus Platyprotus for $P$. phyllosoma. Comparing Platyprotus with Microprotus Richardson, 1910, Storthyngurella Malyutina, 1999 and Storthyngura Just identified (p. 335) the fol- lowing autapomorphies for the genus: flattened body; absence of marginal spines on pereonites 5-7 and pleotelson; absence of preanal ridge of pleotelson, and uniquely spatulate setae on article 3 of the mandibular palp.

We present the comparative characters for Platyprotus and Storthyngura in Table 2. Because of the long list of the characters of Storthyngura defines also Platyprotus and the diagnosis of Platyprotus (Just, 2001: 336) is comprised in the diagnosis of Storthyngura as well, we have reduced the genus Platyprotus to a synonym of Storthyngura. Unique characters of Platyprotus, mentioned by the author are the specific characters of Storthyngura phyllosoma.

The flattened natasoma of $S$. phyllosoma, almost without lateral projections, has the general morphological characteristics of Storthyngura species. It is broader than the ambulosoma; pereonites 5-7 are fused without dorsal sutures, pleotelson is free; anterolateral angles of pereonites 5-7 are more or less acute, posterolateral margins are rounded or straight; two lateral angles of pleotelson vary from rounded and smooth to acute and prominent; terminal projection is about one-third as wide as pleotelson, not pointed apically; margin between posterolateral and terminal projections has rounded notches for uropods. The preanal ridge is weakly developed and hardly produced what is also common for Storthyngura. Unusual marginal setae on article 3 of mandibular palp is a specific character for this species. The same type of distally broadening setae, but with more complicated structure is found in some other species of Storthyngurinae (Malyutina, 2003).

S. phyllosoma has narrow carpus of pereopods $5-7$ and $S$. kussakini is the only species among Storthyngura, which shares this character. Although carpi and propodi 5-7 of S. phyllosoma are narrow and without natatory setae, they are lamellar rather that tubular articles, probably developed from formerly broad swimming articles. This can be assumed because S. phyllosoma, like all Storthyngura species has completely fused pereonites $5-7$. This character, one of the most important for the specialized family Munnopsididae, is linked with swimming or digging capability. S. phyllosoma has the most flattened body and the narrowest posterior legs among the species of Storthyngura. Probably, these are secondary adaptations related to the change from a more swimming to a more creeping lifestyle, which are displayed to different degrees among the species of Storthyngura. 
Table 1

List of species of Storthyngura.

depth (m)

The elegans-group:

S. antarctica sp. nov.

S. elegans Vanhöffen, 1914

Antarctica:

$59-65^{\circ} \mathrm{S}, 53-60^{\circ} \mathrm{W} \quad 1019-2894$

Antarctica:

$65^{\circ} 15^{\prime} \mathrm{S}, 80^{\circ} 19^{\prime} \mathrm{E}$

$71^{\circ} 19^{\prime} \mathrm{S}, 87^{\circ} 37^{\prime} \mathrm{W}$

$59^{\circ} 52^{\prime} \mathrm{S}, 59^{\circ} 03^{\prime} \mathrm{W}$

S. longispina sp. nov.

Antarctica:

$60^{\circ} 38^{\prime} \mathrm{S}, 53-54^{\circ} \mathrm{W} \quad 2893$

S. parka Malyutina \& Wägele, 2001

E. Pacific, off Peru:

$07^{\circ} 08^{\prime} \mathrm{S}, 88^{\circ} 27^{\prime} \mathrm{W}$

3423

400

$3640-3622$

4173

The magnispinis-group:

S.? intermedia (Beddard, 1885)

S. kussakini Brandt \& Malyutina, 2002

N. Pacific:

$37^{\circ} 52^{\prime} \mathrm{N}, 160^{\circ} 17^{\prime} \mathrm{W} \quad 5011$

Antarctica, Weddell Sea:

$71^{\circ} 19^{\prime} \mathrm{S}, 12^{\circ} 24^{\prime} \mathrm{W}$

$65^{\circ} \mathrm{S}, 54^{\circ} \mathrm{W}$

1021

S. magnispinis (Richardson, 1908)

NW. Atlantic:

$39^{\circ} 49^{\prime} \mathrm{N}, 68^{\circ} 30^{\prime} \mathrm{W}$

$63^{\circ} 06^{\prime} \mathrm{N}, 56^{\circ} 00^{\prime} \mathrm{W}$

$61^{\circ} 50^{\prime} \mathrm{N}, 56^{\circ} 21^{\prime} \mathrm{W}$

S. octospinosalis Menzies \& George, 1972

E. Pacific Peru-Chile Trench:

$08^{\circ} 54^{\prime} \mathrm{S}, 80^{\circ} 41^{\prime} \mathrm{W}$

S. phyllosoma (Just, 2001)

Antarctica:

$65^{\circ} 50^{\prime} \mathrm{S}, 50^{\circ} 34^{\prime} \mathrm{E}$

$72^{\circ} 34^{\prime} \mathrm{S}, 22^{\circ} 38^{\prime} \mathrm{W} \quad 938$

S. snanoi Menzies, 1962

W. Atlantic, Caribbean Sea:

$14^{\circ} 05^{\prime} \mathrm{N}, 75^{\circ} 25^{\prime} \mathrm{W} \quad 4071$

S. truncata (Richardson, 1908)

NW. Atlantic, Martha's Vineyard:

$40^{\circ} 29^{\prime} \mathrm{N}, 66^{\circ} \mathrm{W}$

$2788-3235$

NW. Atlantic:

$31^{\circ} 43^{\prime} \mathrm{N}, 68^{\circ} 08^{\prime} \mathrm{W}$

5166
The genus Storthyngura can be split into two groups of species (Tables 1 and 2). One is the elegans-group comprising S. elegans, S. parka, $S$. antarctica sp. nov., and $S$. longispina sp. nov. This group has a terminal projection of the pleotelson with a medial notch; pereonite 1 without a dorsomedial projection; short coxa on pereopod 1; and pereonite 3 without anterolateral projections.

The remaining eight species, included $S$. phyllosoma, we designate as the magnispinis-group. These have a terminal projection on the pleotelson without a medial notch; pereonite 1 with a dorsomedial projection; long pereopod 1 coxa; and pereonite 3 with anterolateral spines. S. intermedia was not examined and its position within Storthyngura is uncertain. Although it shows most characters of magnispinis-group, the pleotelson shape is still unusual for Storthyngura.

Distribution. Five species of the genus Storthyngura have been found in the northern hemisphere including: $S$. intermedia from the North Pacific and four similar species: $S$. magnispinis, S. snanoi, S. truncata, and S.vemae from the West Atlantic (from $14^{\circ}$ to $63^{\circ} \mathrm{N}$ ). All remaining species occur in the southern hemisphere: S. parka, and S. octospinosalis in the East Pacific off Peru and 5 other ones in the Antarctica. The depth range is between 181$5166 \mathrm{~m}$. The shallowest localities were recorded for three southern-most species from the Antarctic continental shelf: S. elegans, S. kussakini and $S$. phyllosoma. S. antarctica occurs between 1019-2894 m, all other species were found deeper than $2000 \mathrm{~m}$.

\section{Storthyngura longispina sp. nov.}

Figs $1-4$

Holotype: female $4.3 \mathrm{~mm}$ long (ZMH, K-40207), 46-7-E, 30.1.2002, nottheast of Elephant Island, South Shetland Islands, $\quad 60^{\circ} 38.33 \mathrm{~S}, \quad 53^{\circ} 57.38 \mathrm{~W}-60^{\circ} 38.17 \mathrm{~S}, \quad 53^{\circ} 57.47 \mathrm{~W}$, 2893-2894 m, epibenthic net. 
Table 2

Comparison of some significant morphological characters between Platyprotus and Storthyngura, including characters, used by Just (2001) for the definition of Platyprotus (lines in bold refer to characters different in the groups of Storthyngura).

\begin{tabular}{|c|c|c|c|}
\hline \multirow[t]{2}{*}{ Character } & \multirow[t]{2}{*}{ Platyprotus } & \multicolumn{2}{|l|}{ Storthyngura } \\
\hline & & magnispinis-group & elegans-group \\
\hline Body shape & flat & $\begin{array}{l}\text { flat (not clear } \\
\text { for } S \text {. octospinosalis) }\end{array}$ & flat \\
\hline Body broadest part & $\begin{array}{l}\text { Natasoma (pereonites } 5-7 \text { and } \\
\text { pleotelson subequal in width) }\end{array}$ & Natasoma (pereonite 5) & Natasoma (pereonite 5) \\
\hline Dorsal spine on head & absent & absent & absent \\
\hline $\begin{array}{l}\text { Dorsomedial spine } \\
\text { on pereonite } 1\end{array}$ & present & present & absent \\
\hline $\begin{array}{l}\text { Coxae of pereopod } 1 \\
\text { Anterolateral spine } \\
\text { on pereonite } 3\end{array}$ & $\begin{array}{l}\text { As long as pereonite laterally } \\
\text { present }\end{array}$ & $\begin{array}{l}\text { As long as pereonite laterally } \\
\text { present }\end{array}$ & $\begin{array}{l}\text { Shorter than pereonite laterally } \\
\text { absent }\end{array}$ \\
\hline $\begin{array}{l}\text { Pereonites } 5-7 \\
\text { articulation }\end{array}$ & Fused without sutures & Fused without sutures & Fused without sutures \\
\hline $\begin{array}{l}\text { Anterolateral angles } \\
\text { on pereonites } 5-7\end{array}$ & slight protruded & protruded & $\begin{array}{l}\text { protruded in different degree } \\
\text { (very weakly in } S \text {. antarctica) }\end{array}$ \\
\hline $\begin{array}{l}\text { Posterolateral margin } \\
\text { on pereonites } 5-7\end{array}$ & rounded & rounded & rounded \\
\hline Pleotelson articulation & free & free & free \\
\hline $\begin{array}{l}\text { Pleotelson lateral } \\
\text { projections }\end{array}$ & Not protruded & Protruded & $\begin{array}{l}\text { Protruded in different degree } \\
\text { (very weakly in } S \text {. antarctica) }\end{array}$ \\
\hline $\begin{array}{l}\text { Pleotelson terminal } \\
\text { projection }\end{array}$ & $\begin{array}{l}\text { Broad, about one third as wide } \\
\text { as pleotelson, not pointed }\end{array}$ & $\begin{array}{l}\text { Broad, about one third as wide } \\
\text { as pleotelson, not pointed }\end{array}$ & $\begin{array}{l}\text { Broad, about one third as wide } \\
\text { as pleotelson, not pointed }\end{array}$ \\
\hline Apex of pleotelson & rounded & rounded & with medial notch \\
\hline $\begin{array}{l}\text { Notches for uropods } \\
\text { between posterolateral } \\
\text { and terminal projections } \\
\text { of pleotelson }\end{array}$ & present & present & present \\
\hline Pleotelson preonal ridge & Weakly developed & $\begin{array}{l}\text { Weakly developed } \\
\text { to different degrees }\end{array}$ & $\begin{array}{l}\text { Weakly developed } \\
\text { to different degrees }\end{array}$ \\
\hline $\begin{array}{l}\text { Article } 1 \text { antenna } 1 \\
\text { medial spine }\end{array}$ & present & present & present \\
\hline $\begin{array}{l}\text { Article } 1 \text { antenna } 1 \\
\text { distomedial projection }\end{array}$ & absent & absent & absent \\
\hline $\begin{array}{l}\text { Article } 1 \text { antenna } 2 \\
\text { articulation }\end{array}$ & Well separated from article 2 & Well separated from article 2 & Well separated from article 2 \\
\hline $\begin{array}{l}\text { Article } 1 \text { antenna } 2 \\
\text { lateral spine }\end{array}$ & present & present & present \\
\hline $\begin{array}{l}\text { Mandible pars incisive } \\
\text { in dorsoventral view }\end{array}$ & narrow & narrow & narrow \\
\hline Mandible lacinia mobilis & stout & stout & stout \\
\hline Mandible spine row & $8-11$ stout setae & $8-11$ stout setae & $8-11$ stout setae \\
\hline $\begin{array}{l}\text { Mandible molar } \\
\text { process distally }\end{array}$ & narrow & narrow & narrow \\
\hline $\begin{array}{l}\text { Mandible palp } \\
\text { article } 3 \text { setae }\end{array}$ & Long spatulate & Short simple & Short simple \\
\hline Maxilliped endite & with few slender coupling hooks & with few slender coupling hooks & with few slender coupling hooks \\
\hline $\begin{array}{l}\text { Maxilliped palp } \\
\text { article } 2 \text { medial margin }\end{array}$ & $\begin{array}{l}\text { Somewhat concave, } \\
\text { longer than article } 3\end{array}$ & $\begin{array}{l}\text { Somewhat concave, } \\
\text { longer than article } 3 \\
\text { (subequal in S. kussakini) }\end{array}$ & $\begin{array}{l}\text { Somewhat concave, } \\
\text { longer than article } 3\end{array}$ \\
\hline $\begin{array}{l}\text { Maxilliped epipod } \\
\text { lateral margin }\end{array}$ & smooth & $\begin{array}{l}\text { Smooth (angular } \\
\text { in } S . \text { kussakini) }\end{array}$ & smooth \\
\hline Pereopods $3-4$ & $\begin{array}{l}\text { Insignificantly longer } \\
\text { than pereopod } 2\end{array}$ & $\begin{array}{l}\text { Insignificantly longer } \\
\text { than pereopod } 2\end{array}$ & $\begin{array}{l}\text { Insignificantly longer } \\
\text { than pereopod } 2\end{array}$ \\
\hline $\begin{array}{l}\text { Carpi of pereopods } \\
3-4\end{array}$ & $\begin{array}{l}\text { Stout, with spine-like ventral } \\
\text { setae on distal third }\end{array}$ & $\begin{array}{l}\text { Stout, with spine-like ventral } \\
\text { setae on distal third }\end{array}$ & $\begin{array}{l}\text { Stout, with spine-like ventral } \\
\text { setae on distal third }\end{array}$ \\
\hline
\end{tabular}


Table 2

Continued

\begin{tabular}{|c|c|c|c|}
\hline \multirow[t]{2}{*}{ Character } & \multirow[t]{2}{*}{ Platyprotus } & \multicolumn{2}{|l|}{ Storthyngura } \\
\hline & & magnispinis-group & elegans-group \\
\hline $\begin{array}{l}\text { Carpi of pereopods } \\
5-7\end{array}$ & $\begin{array}{l}\text { Elongate, not broader } \\
\text { than basis, without } \\
\text { natatory setae }\end{array}$ & $\begin{array}{l}\text { broader than basis, crescent- } \\
\text { shaped (in } S . \text { kussakini } \\
\text { elongate, not broader than } \\
\text { basis, natatory setae tend } \\
\text { to reduction on ventral margin) }\end{array}$ & $\begin{array}{l}\text { broader than basis, } \\
\text { crescent-shaped }\end{array}$ \\
\hline $\begin{array}{l}\text { Propodi of pereopods } \\
5-7\end{array}$ & Elongate, smaller than carpus & Elongate, smaller than carpus & Elongate, smaller than carpus \\
\hline Male pleopod 1 & $?$ & $\begin{array}{l}\text { Broadest basally, } \\
\text { tapering distally }\end{array}$ & $\begin{array}{l}\text { Broadest basally, } \\
\text { tapering distally }\end{array}$ \\
\hline $\begin{array}{l}\text { Male/female } \\
\text { pleopod } 2 \text { setae }\end{array}$ & Long plumose & Long plumose & Long plumose \\
\hline $\begin{array}{l}\text { Male pleopod } 2 \\
\text { protopod }\end{array}$ & Medial margin concave & Medial margin concave & Medial margin concave \\
\hline Male pleopod 2 stylet & $\begin{array}{l}\text { More than two-thirds } \\
\text { as long as protopod }\end{array}$ & $\begin{array}{l}\text { More than two-thirds } \\
\text { as long as protopod }\end{array}$ & $\begin{array}{l}\text { More than two-thirds } \\
\text { as long as protopod }\end{array}$ \\
\hline $\begin{array}{l}\text { Plumose distal setae } \\
\text { on pleopod } 3 \text { endopod }\end{array}$ & $3-4$ & 3-4 (8 in S. kussakini) & 3 \\
\hline Pleopod 3 exopod & $\begin{array}{l}\text { Broad distally, with } \\
7-9 \text { plumose setae }\end{array}$ & $\begin{array}{l}\text { Broad distally, with } \\
5-8 \text { plumose setae }\end{array}$ & $\begin{array}{l}\text { Broad distally, with } \\
5-9 \text { plumose setae }\end{array}$ \\
\hline Pleopod 4 exopod & $\begin{array}{l}\text { Elongate, not reaching apical } \\
\text { margin of endopod, } \\
\text { with } 1 \text { distal seta }\end{array}$ & $\begin{array}{l}\text { Elongate, not reaching apical } \\
\text { margin of endopod, } \\
\text { with } 1-2 \text { distal seta }\end{array}$ & $\begin{array}{l}\text { Elongate, not reaching apical } \\
\text { margin of endopod, } \\
\text { with } 1 \text { distal setae }\end{array}$ \\
\hline
\end{tabular}

Paratype: female (ZMH, K-40208), 46-7-S, same locality, suprabenthic net.

Type locality: northeast of Elephant Island, South Shetland Islands, Antarctica.

Description of holotype. Body (Fig. 1) 1.8 times as long as pereonite 5 , height 0.2 of length. Head (Figs 1,2) midline from point between antennae 1 to posterior margin 0.4 times as long as wide; interantennular distance 0.15 times as wide as head, 0.6 times as wide as antenna 1 basally; frontal arch triangular, with low lateral ridges; clypeus 1.5 times as broad and 0.3 as long as labrum.

Pereonite 1 almost half as long as each of subequal pereonites 2-4. Posterolateral corners of all ambulosomal pereonites rounded, rough in pereonite 3 and 4; anterolateral corners of pereonites 1-3 angular in dorsal view, without projections, pereonite 4 with narrow anterolateral spines. Pereonite 1 without dorsal spine, anterior margin of pereonites 2-4 each with anteriorly directed pointed median spine; spines on pereonites 2 and 3 subequal in length, 1.5 times as long as pereonite length, spine on pereonite 4 shorter and narrower than those on pereonites 2 and 3. Coxae of pereopod 1 shortest, shorter than pereonite; anterior coxal spine of pereopod
2 subequal in length to pereonite; posterior coxal projection almost invisible in dorsal view; anterior spines of coxae 3 and 4 subequal in length to dorsomedial spines of pereonites 2 and 3, curved, basally narrow, with lateral spine-like stout seta in midlength; posterior coxal spines slender, half as long as anterior ones.

Natasoma about 1.2 times as long as anterior body part (ambulosoma + head). Pereonite 5 very short medially, with 1 slender dorsomedial spine anteriorly, half as long as that of pereonite 4; pereonites 6 and 7 with pair of low indistinct submedian dorsal tubercles; anterolateral projections pointed, directed almost perpendicular to body axis, slightly frontally, twice as long as pereonites laterally.

Pleotelson (Fig. 1) 0.3 times as long as body, 0.7 times as long as wide together with anterior spines and 1.2 as long as wide across middle part. Anterolateral spines directed perpendicular to body axis; posterolateral spines slightly shorter than anterolateral spines, pointed, directed posteriorly; terminal projection 0.4 times as long as pleotelson, 1.4 times as long as wide apically, apex with deep angular median notch; lateral spines and terminal projection bent dorsally; dorsal surface of pleotelson with small acute tubercles posterior to rounded elevation on anterior 


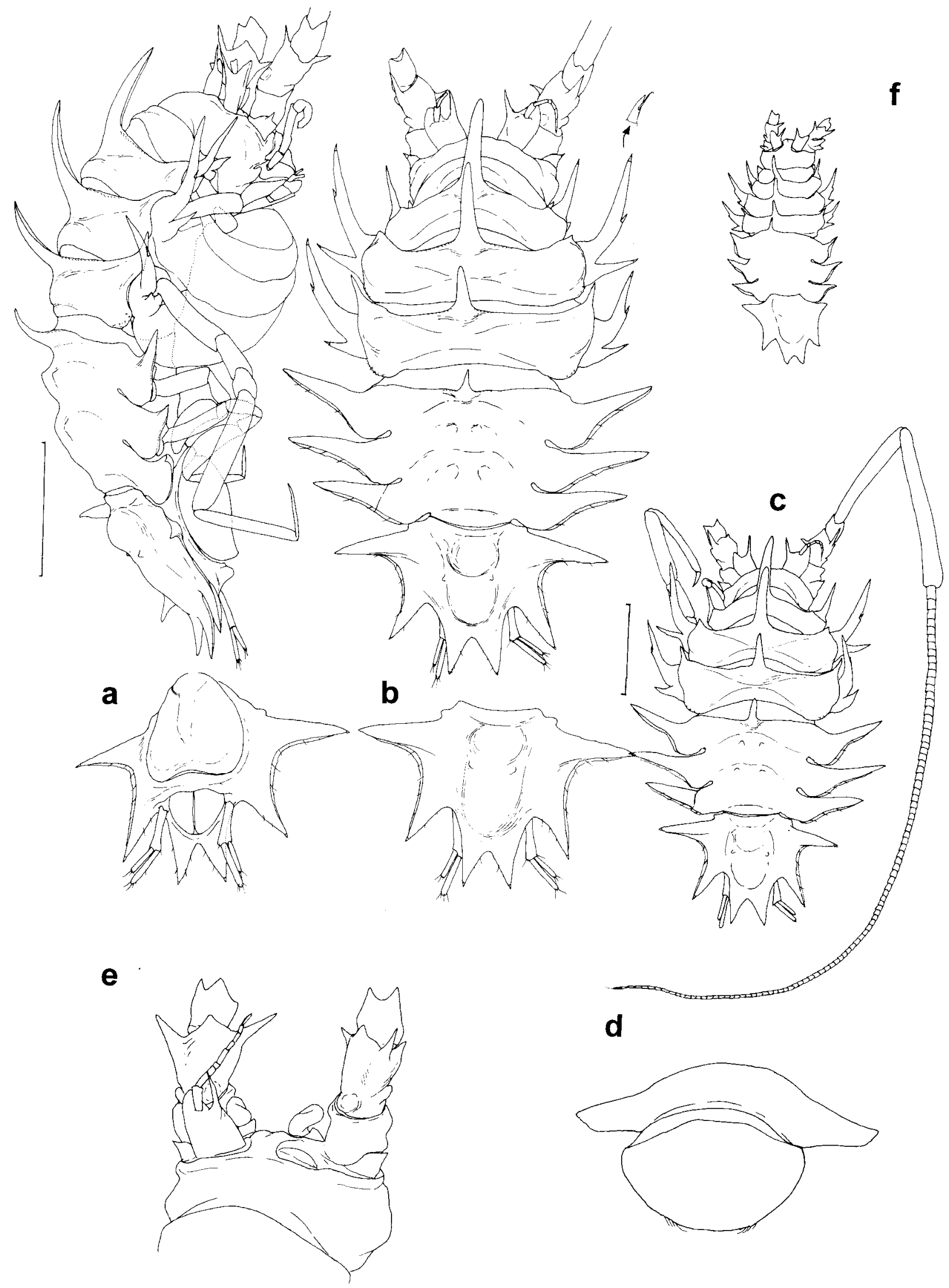

Fig. 1. Storthyngura longispina sp. nov., female, holotype: dorsal and lateral total body views; $\mathbf{a}, \mathbf{b}$, pleotelson: $\mathbf{a}$, ventral and $\mathbf{b}$, dorsal view; c, total body with antenna 2 ; $\mathbf{d}$, labrum and clypeus; $\mathbf{e}$ juvenile, total dorsal view. 
part; preanal ventral ridge very short, rounded, not bent posteriorly.

Antenna 1 (Fig. 2) about 0.2 times as long as body, 8 articles; article 11.8 times as long as wide, medial spine half as long as article; article 2 subequal to distolateral lobe of article 1 ; articles $3-80.8,0.2,0.7,0.4,0.4,0.4$ times as long as article 2 respectively, only slightly narrower than article 2; article 2 with 3 and article 4 with 2 distal broom setae; terminal article with 2 aesthetascs and 3 small simple setae.

Antenna 2 (Fig. 1) 2.8 times as long as body. Peduncle article 1 with distolateral minute spinelike projection; article 3 almost twice as long as article 2 dorsally, with subequal lateral and medial distal spines, both ending with stout spine-like seta; article 51.5 times as long as articles $1-4$ combined; article 61.4 times as long as article 5; flagellum of about 100 articles.

Mandibles (Fig. 2): pars incisiva with 1 large tooth and 1 weak cusp proximally (indistinct on right mandible); lacinia mobilis of left mandible stout, 0.8 times as long as pars incisiva, with 4 teeth; spine row with 8 and 10 members on left and right mandibles respectively; molar process tapering distally, ventral margin of triturative surface with row of denticles and 5 setulose setae; condyle 0.2 times as long as mandibular body; palp slightly longer (1.1) than mandibular body, article 23.3 times as long as article 1, with 2 short distal setae, article 3 relatively narrow, with row of rather short marginal setulose setae.

Maxilla 1 (Fig. 3) lateral endite 1.5 times as wide as mesial endite.

Maxilla 2 (Fig. 3) mesial endite longest, with dense tuft of setae distally, 5 of which are comblike, middle endite shortest, additional small distomedial seta stout; lateral endite with thin distomesial seta.

Maxilliped (Fig. 2) endite with 4 coupling hooks, distal margin with 4 large fan setae and numerous simple slender setae, lateral margin and dorsal ridge with long setae, basis lateral margin with dense row of hair-like setae; palp article 2 lateral margin 1.2 times as long as medial margin, which slightly concave; article 3 medial margin 0.7 as long as article 2 , moderately convex, with short setulose setae; article 4 longer laterally than articles 3 and 5, medial lobe longer than article 5, with 4 distal setae, article 5 with 4 distal setae. Epipod 2.6 times as long as wide, distal angle rounded, lateral margin convex, with transparent fringe.

Basis of pereopods 2-7 subequal in size, basis of pereopod 1 shortest, about 0.7 times as long as each following basis. All bases with numerous small simple setae and a few small broom setae.

Pereopod 1 (Fig. 3) 0.3 times as long as body, ischium 0.4 and merus 0.2 times as long as basis, with sparse small setae; carpus longest, 1.2 times as long as basis, slightly curved; propodus 0.6 as long and about as wide as carpus, both articles with small marginal setae; dactylus half as long as propodus.

Pereopod 2 (Fig. 3) ischium 0.6 and merus 0.3 times as long as basis, with sparse small setae; carpus slightly longer than basis, propodus longest, 1.1 times as long as carpus, both articles about twice as wide as the same articles in pereopod 1; carpus with ventral fringe, including 3 or 4 simple small setae and 6 dorsal simple setae; propodus with small 10 dorsal, 1 broom and 2 or 3 distodorsal whip setae and 7 ventral spine-like setae; dactylus more than half as long as propodus.

Pereopods 3 and 4 (Fig. 3, 4) robust, subequal in length. Pereopod 3 carpus 1.4 as long as basis, 3 stout setae on distal third of ventral margin; propodus 1.2 as long as carpus, with simple short marginal setae; dactylus half as long as propodus. Pereopod 4 basis somewhat shorter than that in pereopod 3; carpus and propodus slightly longer and carpus slightly broader than that of pereopod 3; carpus with 4 stout setae on distal third ventrally; dactylus less than twice as long as propodus.

Pereopods 5-7 (Fig. 3, 4) of similar shape, about 0.8 times as long as pereopod 2. Pereopod 5 basis and ischium somewhat stouter than those of pereopods 6 and 7. Ischium 5-7 slightly more than half as long as corresponding basis. All carpi of the same shape, about 2.5 times as long as wide; carpus 5 and 6 subequal in length to basis; carpus 7 slightly shorter than basis $(0.85)$; propodi 5-7 shorter than carpi (0.9), both articles with plumose marginal setae, distodorsal margin of propodi serrated; dactyli $0.7-0.8$ times as long as corresponding propodi.

Operculum (Fig. 1) as long as wide; keel rather high, narrow, rounded ventrally, distal margin with many plumose setae.

Pleopod 3 (Fig. 4) endopod 1.7 times as long as wide, 3 plumose setae distally. Exopod 1.1 times as long as endopod, basal article 0.25 times as wide as endopod, articles subequal in length, apical one with 8 distal plumose setae and dense rows of long hair-like lateral setae.

Pleopod 4 (Fig. 4) endopod slightly larger than that of pleopod 3,1.4 times as long as wide. Exopod 0.2 times as wide and 0.8 as long as endopod. 


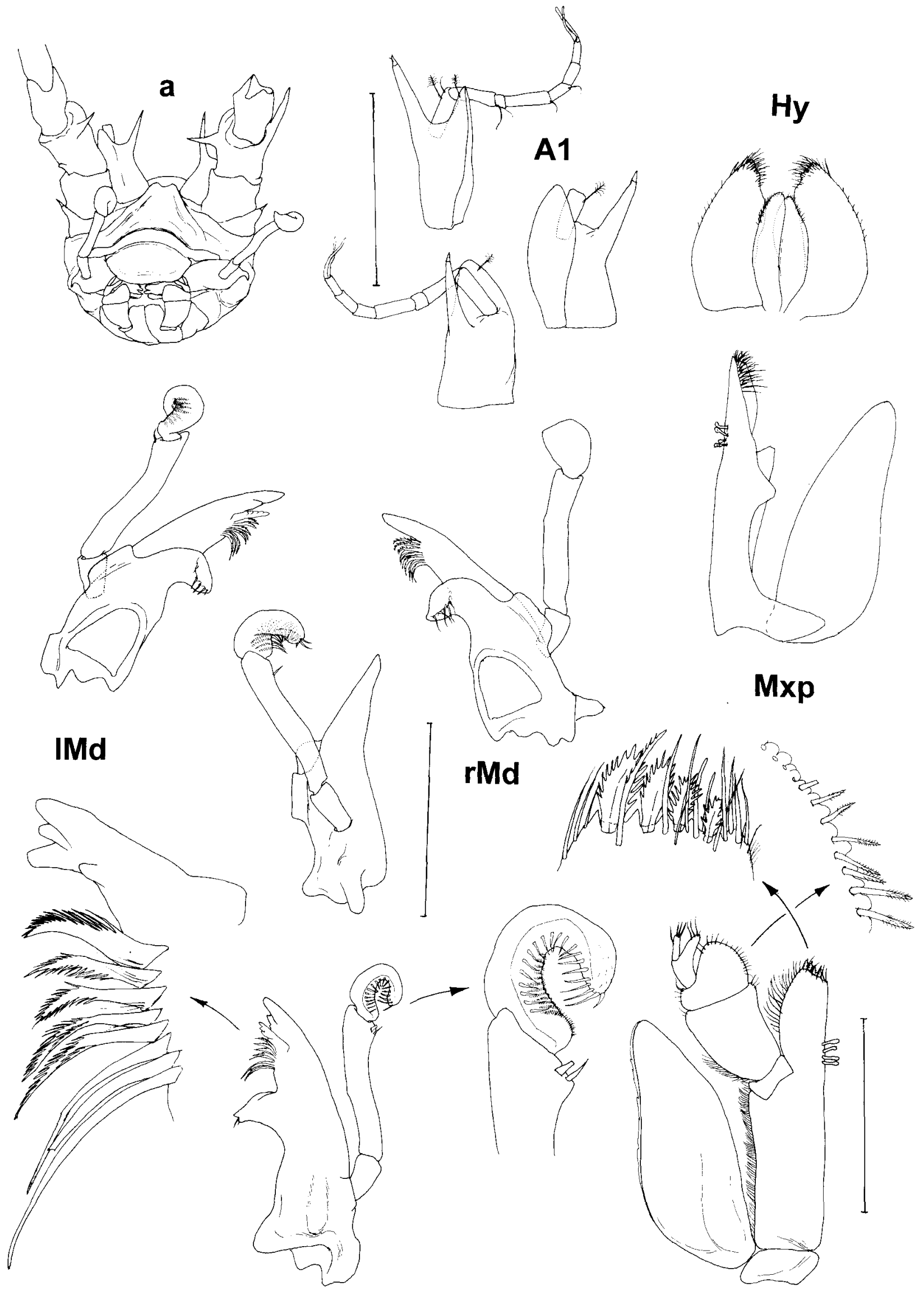

Fig. 2. Storthyngura longispina sp. nov., female, holotype: a, head, frontal view; antenna 1, mandibles, and maxilliped. 


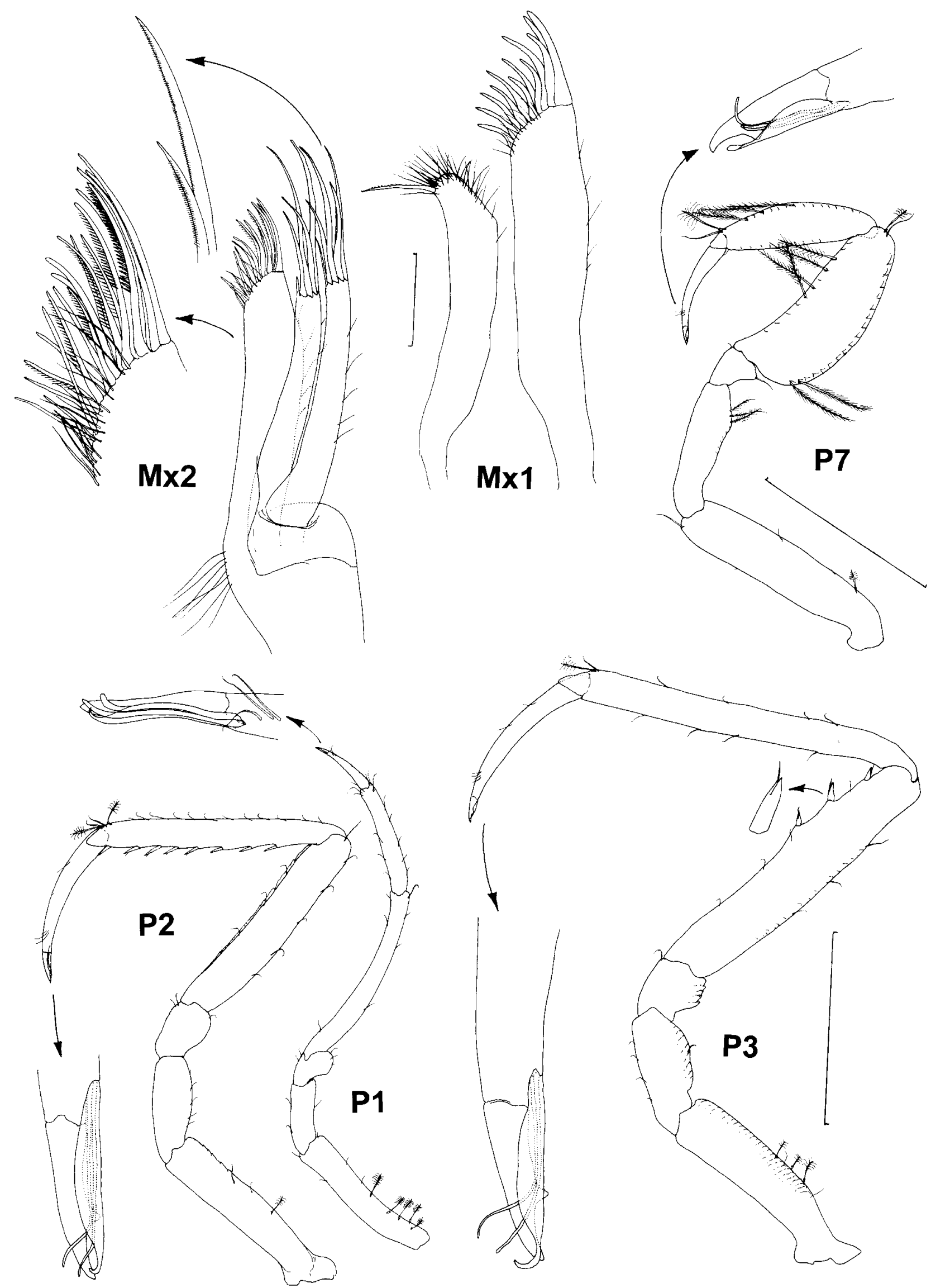

Fig. 3. Storthyngura longispina sp. nov., female, holotype: maxillae, pereopods $1-3$ and 7 . 


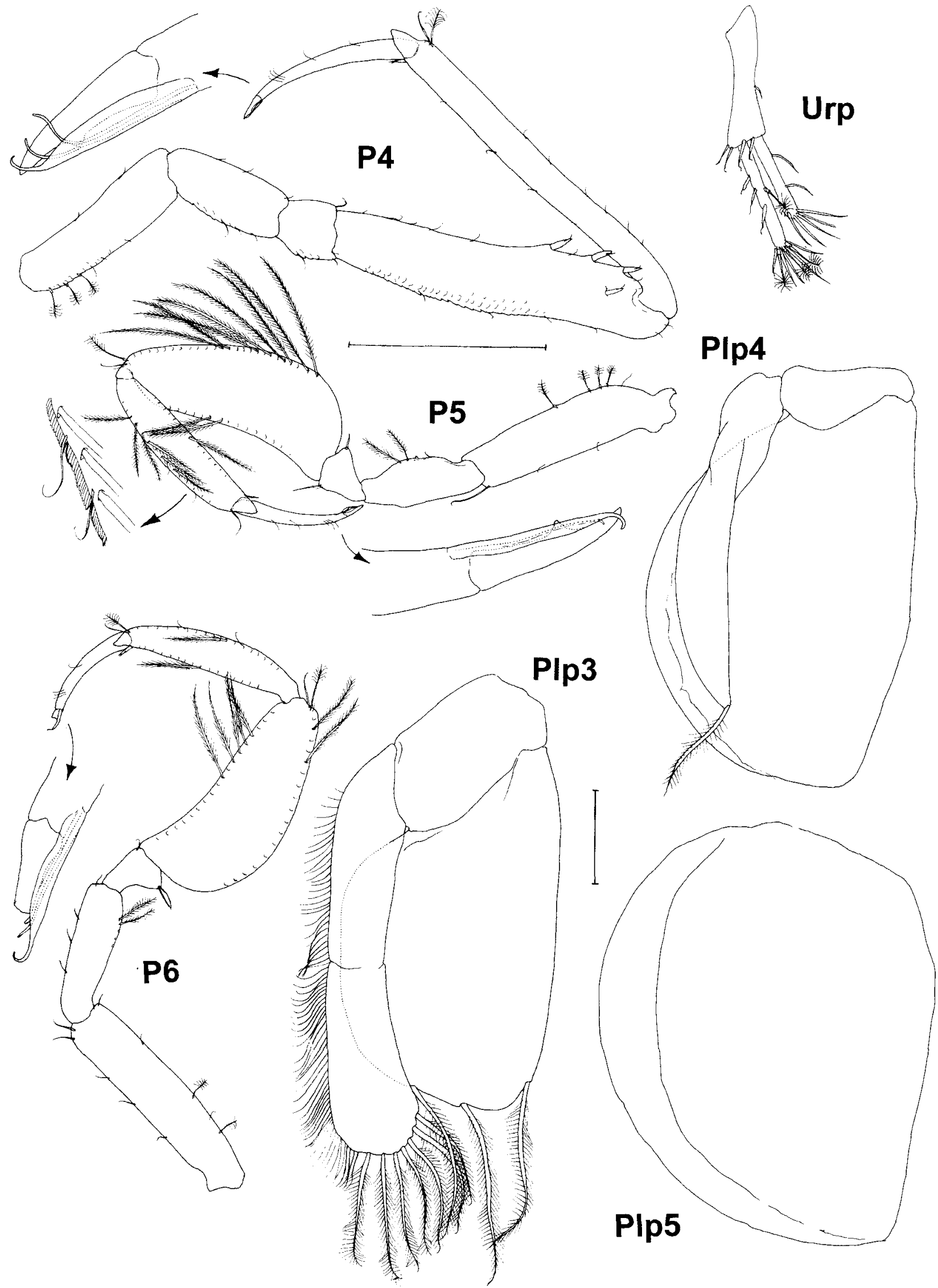

Fig. 4. Storthyngura longispina sp. nov., female, holotype: pereopods 4-6, pleopods 3-5 and uropod. 
Pleopod 5 (Fig. 4) endopod 11.2 times as long as wide.

Uropod (Fig. 4) 0.5 times as long as pleotelson. Protopod 2.6 times as long as wide, conspicuously broadening distally, with 2 distomedial and 2 distolateral long whip setae. Endopod less than half as wide as protopod, subequal to protopod in length, with 1 medial bifid seta, 4 lateral whip setae, 3 distal broom and 5 simple setae. Exopod 0.7 times as long and as wide as endopod, with 2 whip and 5 simple setae distally.

\section{Male. Unknown.}

Etymology. From the Latin longus in combination with spina (thorn) referring to the long dorsal and lateral spine-like projections of the body and coxae of pereopods 3-4.

Distribution. Antarctica: Drake Passage off South Shetland Islands; at a depth 2893-2894 m.

Re marks. Storthyngura longispina sp. nov. differs from all species of the genus in having a single dorsomedial spine on pereonite 5, long dorsal spines on pereonites 2-4 and long spines on coxae 3-4, with spine-like seta on the middle of lateral margins. The shape of the pleotelson of the new species is similar to that of S. elegans Vanhöffen, 1914, but Storthyngura longispina sp. nov. can be easily distinguished from $S$. elegans by having all spines on the body and coxae and medial spine on article 1 of antenna 1 longer than in S. elegans.

\section{Storthyngura antarctica sp. nov.}

Figs 5-10

Holotype: male $4.1 \mathrm{~mm}$ long (ZMH, K-40209), 46-7-S 30.1.2002, northeast of Elephant Island, South Shetland Islands $\quad 60^{\circ} 38.33 \mathrm{~S}, \quad 53^{\circ} 57.38 \mathrm{~W}-60^{\circ} 38.17 \mathrm{~S}, \quad 53^{\circ} 57.47 \mathrm{~W}$, 2893-2894 m, suprabenthic net.

Paratypes: (paratypes ZMH, K-40210), 1 female, 1 male, 1 male on IV stage, 46-7-E, the same locality as holotype, epibenthic net; (paratype ZMH, K-40211), 1 male, 41-3-E, 26. 1. 2002, $59^{\circ} 22.24 \mathrm{~S}, 60^{\circ} 04.06 \mathrm{~W}-59^{\circ} 22.39 \mathrm{~S}, 60^{\circ} 04.00 \mathrm{~W}$ 2368-2370 m; (paratype ZMH, K-40212), 1 female, 133-3-E, 7. $3.2002,65^{\circ} 20.17 \mathrm{~S}, 54^{\circ} 14.30 \mathrm{~W}-65^{\circ} 20.05 \mathrm{~S}, 54^{\circ} 14.46 \mathrm{~W}$, $1021-1019 \mathrm{~m}$.

Type locality: northeast of Elephant Island, South Shetland Islands, Antarctica.

Description. Body of the holotype (Fig. 5), paratype male and female (Fig. 6), twice as long as pereonite 5 . Head 0.5 times as long as wide; interantennular distance 0.1 times as wide as head and 0.5 as antenna 1 ; frons concave medi- ally, frontal arch triangular, with thick lateral ridges; clypeus 1.5 times as broad and 0.4 as long as labrum.

Pereonites 1-4 subequal in length medially, posterolateral corners of all of them rounded, anterolateral corners of pereonites $1-3$ rounded, without projections, pereonite 4 with anterolateral spines; pereonite 1 without dorsal spine, anterior margin of pereonites $2-4$ with dorsomedial projection, rounded distally on pereonites 2 and 3, and pointed on pereonite 4; spines subequal in length, curled, longer than pereonite. Anterior coxal spine of pereonite 1 smallest, about 0.25 as long as following ones, which are triangular, pointed, longer than pereonites; anterior coxal spines 3 and 4 subequal in length to dorsomedial spines of pereonites 2 and 3, posterior coxal projections small, in pereopod 2 almost not produced.

Natasoma 1.5 as long as anterior part of body; pereonite 5 without dorsomedial spines, anterior margin slightly raised; pereonites 6 and 7 with pair of dorsal low elevations; anterolateral projections weakly produced, lateral margins of natasoma almost in one line.

Pleotelson 0.3 times as long as body, 0.7 times as long as wide anteriorly (with spines) and 0.9 as wide in middle part; anterolateral processes broad, rounded distally; posterolateral projections narrower than anterolateral ones, more acute, posteriorly directed; lateral margins almost straight, weakly concave; terminal projection short and broad, 0.3 times as long as pleotelson, 0.7 times as long as wide apically, with shallow angular medial notch; lateral and terminal projections somewhat bent dorsaly; dorsal surface with central elevation, pair of small acute tubercles on anterior half of pleotelson; preanal ventral ridge short, rounded, slightly produced posteriorly.

Antenna 1 of male (Fig. 7) about half as long as body. Article 11.8 times as long as wide, medial spine small, narrow, 0.2 times as long as article; article 2 half as long as article 1, visibly longer than distolateral lobe of article 1; articles 3-7 conspicuously narrower than article 2, 0.7, $0.2,0.9,0.2,0.1$ times as long as article 2 respectively; following 53 flagellar articles as long as article 7 , terminal half of flagellum with aesthetascs.

Antenna 1 of female (Fig. 7) about 0.2 times as long as body, 13 articles. Article 11.7 times as long as wide, medial spine of the same length, but broader than that in male; article 2 slightly longer than distolateral lobe of article 1 ; articles 

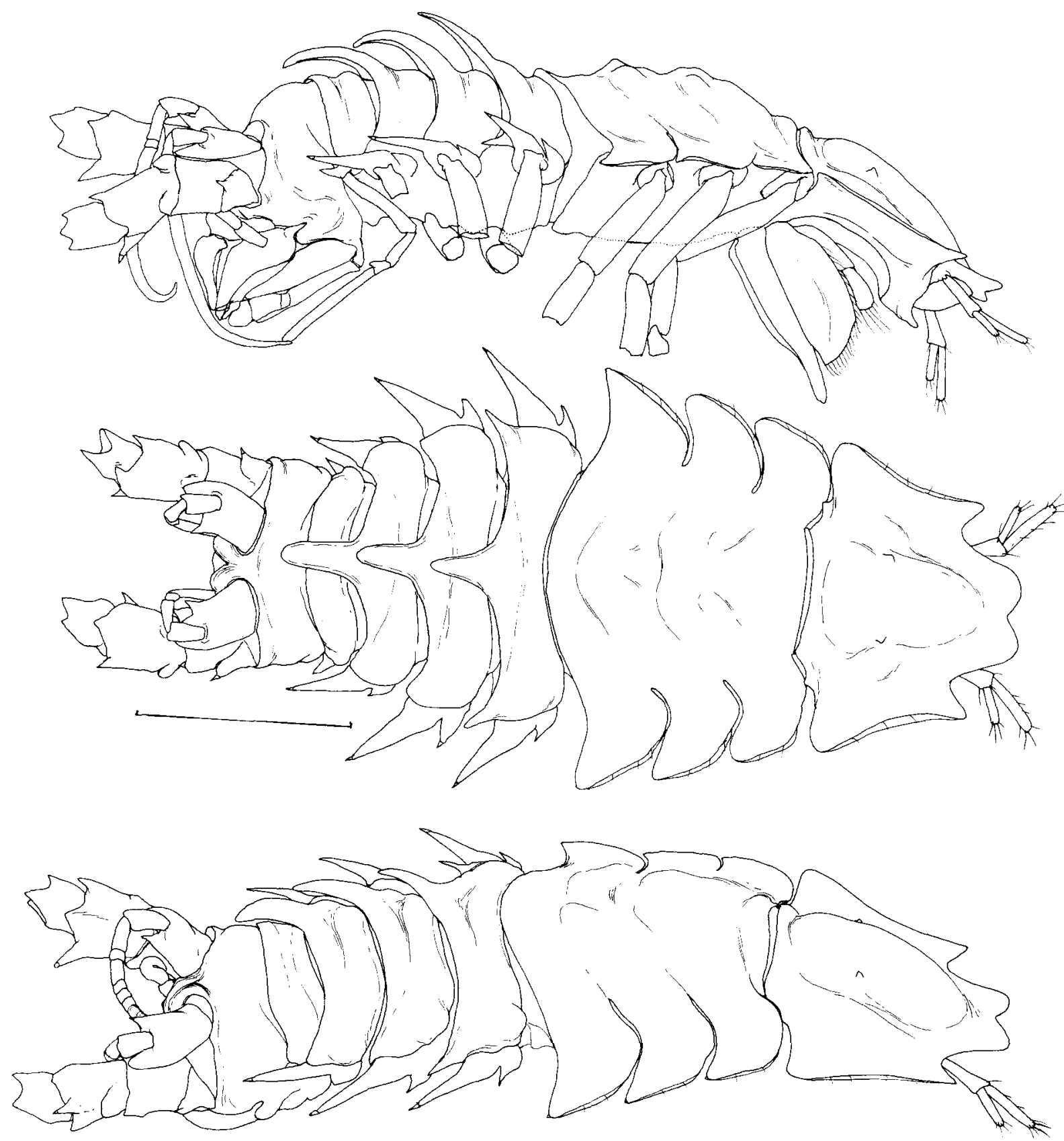

a

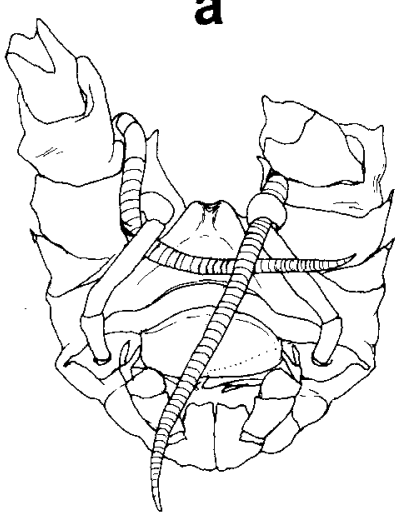

b

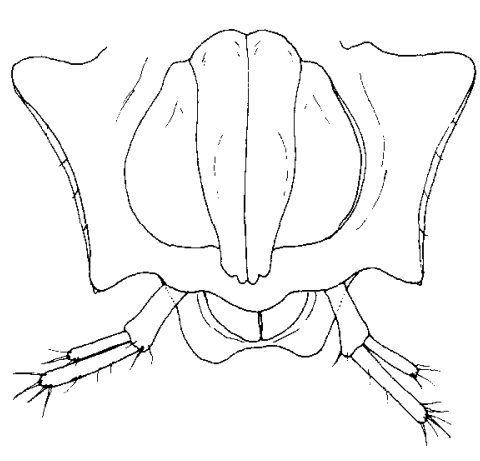

C

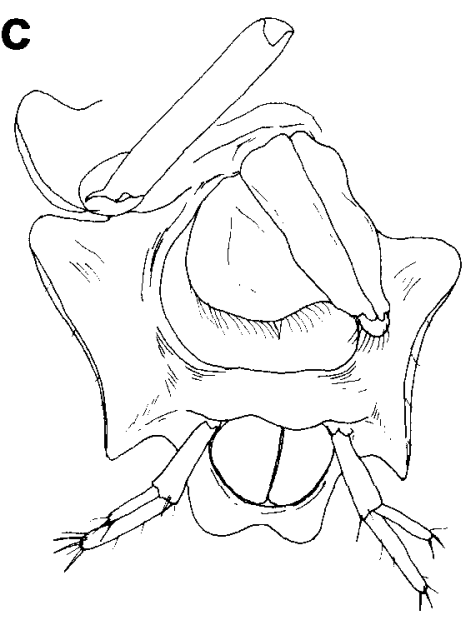

Fig. 5. Storthyngura antarctica sp. nov., male, holotype: dorsal and lateral body views; a, head, frontal view; b, pleotelson, ventral view; c, pleotelson, ventral oblique view. 


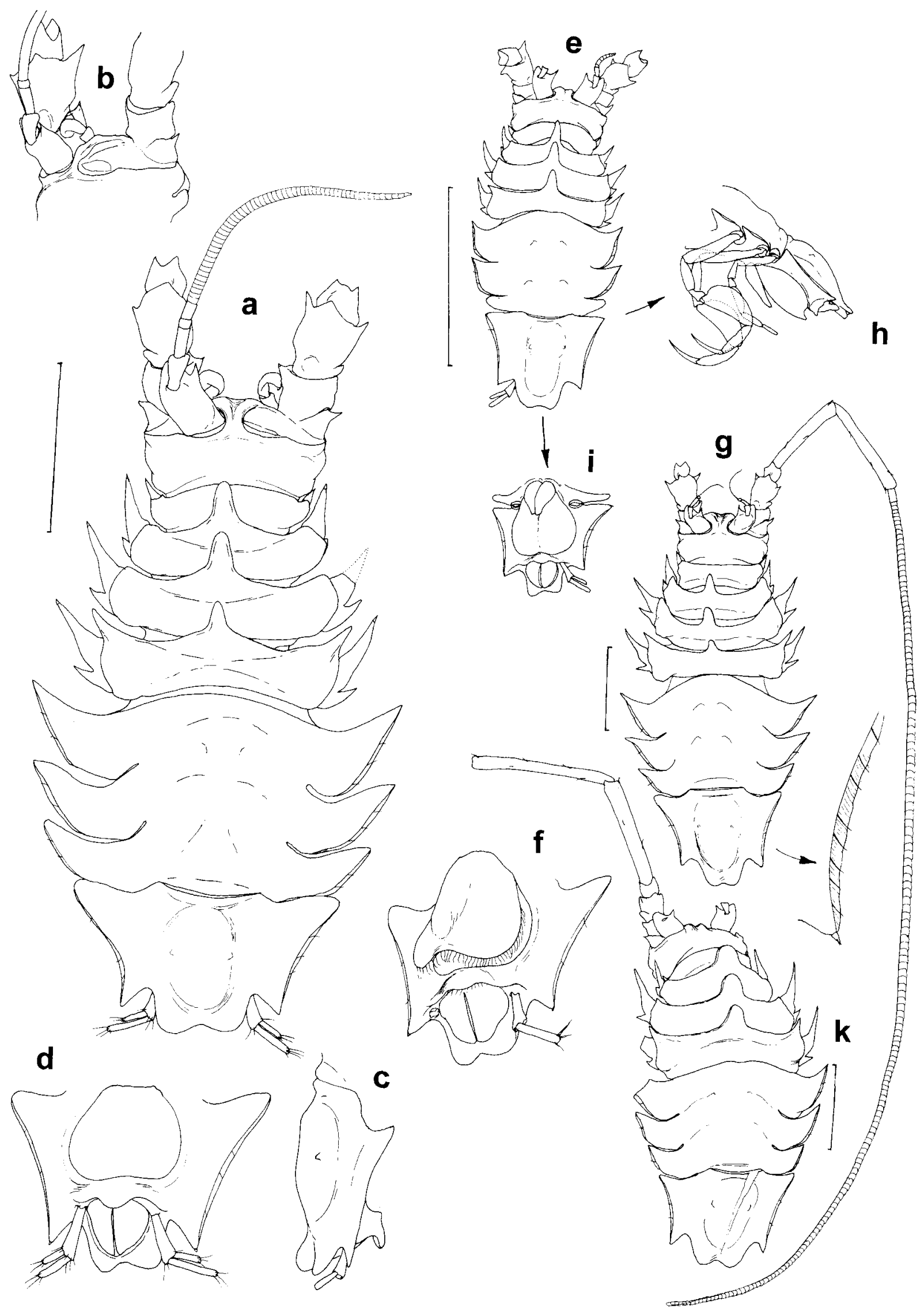

Fig. 6. Storthyngura antarctica sp. nov., male, paratype: a, dorsal body view; b, head without right antenna 1, oblique lateral view; c, pleotelson, lateral view; $\mathbf{d}$, pleotelson, ventral view; g, , female, paratype: $\mathbf{g}$, dorsal total view and $\mathbf{f}$, pleotelson, ventral view; $\mathbf{e}, \mathbf{h}, \mathbf{i}$ male on IV stage: $\mathbf{e}$, total dorsal view, $\mathbf{h}$, natasoma, lateral view and $\mathbf{i}$, pleotelson ventral view; $\mathbf{k}$, female, paratype, dorsal total view. 


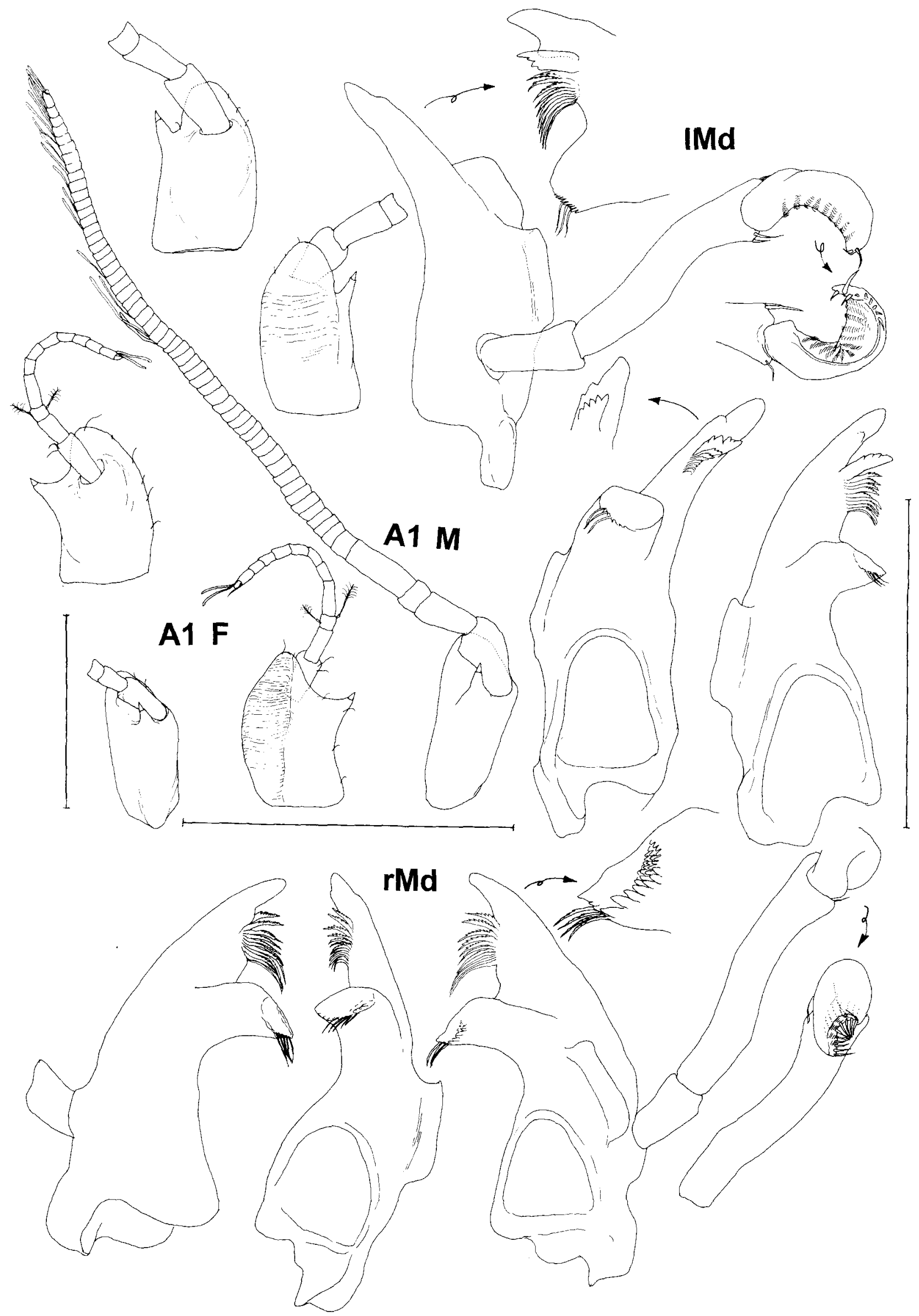

Fig. 7. Storthyngura antarctica sp. nov., male and female, paratypes: antenna 1; male, paratype: mandibles. 
$3-60.7,0.2,0.7,0.35$ times as long as article 2 respectively; following 6 flagellar articles as long as article 6 , terminal article smallest, with two aesthetascs and small simple seta; all articles excepting basal one half as wide as those in male.

Antenna 2 of male (Fig. 7) broken, four basal articles preserved only. Distolateral minute spine-like projection of article 1 subequal to distomedial projection of article 2; article 3 almost twice as long as article 2 dorsally, with subequal lateral and medial spines distally, both ending with stout spine-like seta.

Antenna 2 of female (Fig. 6) 2.9 times as long as body. Articles $1-4$ as those in male, article 5 slightly longer than articles $1-4$ combined, article 61.2 times as long as article 5, both of them with sparse setae along, flagellum of about 180 articles.

Mandibles (Fig. 7). Pars incisiva with one large tooth and one weak cusp proximally; lacinia mobilis of left mandible 0.6 times as long as pars incisiva, with five teeth; spine row with 10 and 11 members in left and right mandibles respectively; molar process tapering distally, ventral margin of triturative surface with row of denticles and four or five setulose setae; condyle 0.2 times as long as mandibular body. Palp subequal in length to mandibular body, article 22.6 times as long as article 1 , with two short distal setae, article 3 with row of rather short marginal setulose setae.

Maxilla 1 (Fig. 8) lateral endite 1.5 times as wide as mesial endite.

Maxilla 2 (Fig. 8) mesial endite longest, with dense tuft of setae distally, 5 of them comb-like; middle endite shortest, distal spine-like setae longer than those on lateral endite, additional small distomesial seta stout.

Maxilliped (Fig. 8) endite with 5 coupling hooks, distal margin with 4 broad fan setae and numerous thin setae, lateral margin and dorsal ridge with long setae; basis with dense row of hair-like lateral setae; palp article 2 medial margin 0.8 as long as lateral margin; article 3 0.2 times as long laterally and 0.7 medially as article 2 , medial margin moderately convex, with short setae; article 4 longer than articles 3 and 5 laterally, medial lobe shorter than article 5 , both with 5 distal setae; epipod 2.8 as long as wide, rounded distally.

Pereopod bases increasing in length from 1 to 7 , with numerous small simple setae and a few small broom setae dorsally.

Pereopod 1 of male (Fig. 8) 0.3 times as long as body, ischium half and merus 0.2 times as long as basis, with sparse thin setae; carpus longest, 1.1 as long as basis, almost straight; propodus 0.6 times as long and almost as wide as carpus, both articles with small setae along and tuft of distal setae; dactylus 1.2 as long as merus.

Pereopod 2 of male (Fig. 8) carpus 1.25 times as long as basis, 6 times as long as wide; propodus longest, 1.1 times as long as carpus, both articles twice as wide as the same articles in pereopod 1, with small setae, carpus with a stout seta on ventral third of ventral margin; dactylus broken in this specimen.

Pereopod 3 of male (Fig. 8) almost twice broader and about 1.5 times as long as pereopod 2; carpus 1.7 times as long as basis, 4.5 times as long as wide, narrowing distally, with two rows of 6 and 3 stout setae on distal third of ventral margin; propodus longest, 1.2 times as long as carpus, with sparse small setae; dactylus half as long as carpus, with thin simple setae along.

Pereopod 4 broken off in all specimens.

Pereopod 3 of female (Fig. 9) carpus 4.8 times as long as wide, with two rows of 4 and 2 setae on distal third of ventral margin and 8 dorsal small setae; propodus broken off.

Pereopod 4 of female (Fig. 9) carpus 5 times as long as wide, with two rows of 5 setae each on distal third of ventral margin and 1 seta in midlength; propodus 1.2 times as long as carpus; dactylus about half as long as carpus.

Pereopods 5-7 (Fig. 9) of similar shape. Ischia 5-7 slightly more than half as long as corresponding basis $(0.57,0.64,0.61)$; carpi 6 and 7 subequal in length to bases 6,7 ; carpus 5 1.2 times as long as basis, 2.5 times as long as wide; propodi $5-7$ about 0.8 as long as carpi, both margins with plumose setae, distodorsal margin of propodi serrated, with whip setae; dactyli 5-7 half as long as carpi 5-7.

Pleopod 1 of male (Fig. 10) straight, stout, without waist in midlength, 2.5 times as long as wide basally, tapering distally, distal margin 0.25 as wide as basal margin; distodorsal one-fourth with two rows of short, simple setae.

Pleopod 2 of male (Fig. 10) protopod 0.7 as long as pleopod 1 and twice as long as wide; medial margin concave, lateral margin rounded, distal third with long plumose setae; stylet 0.9 times as long as protopod, extending beyond distal margin of protopod; exopod slender, with long setules on posterior margin of bend.

Pleopod 2 of female (Fig. 6) as long as wide; keel rather high, narrow, rounded ventrally, distal margin with many plumose setae. 


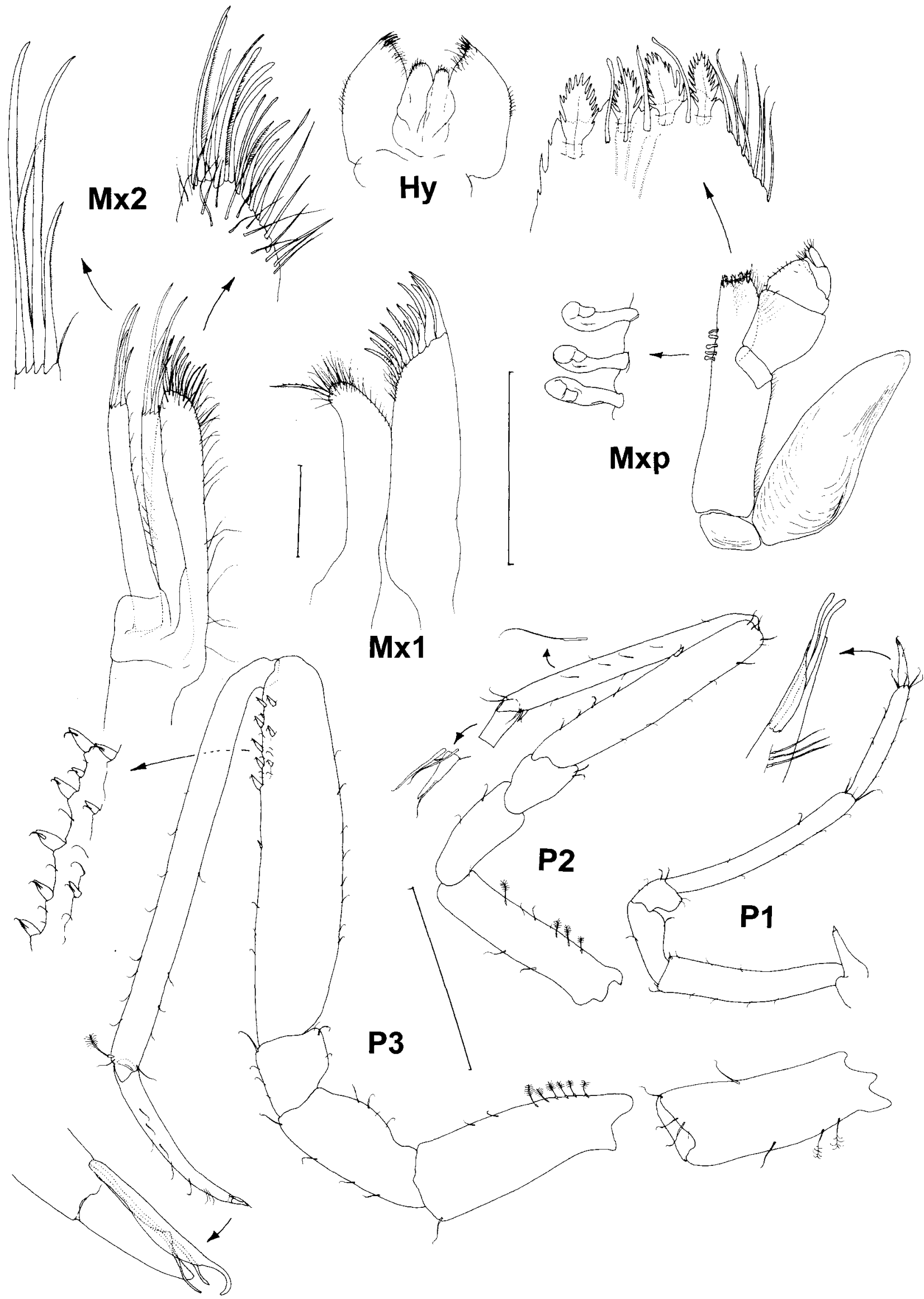

Fig. 8. Storthyngura antarctica sp. nov., male, paratype: mouthparts, pereopods $1-3$, basis of pereopod 4 . 

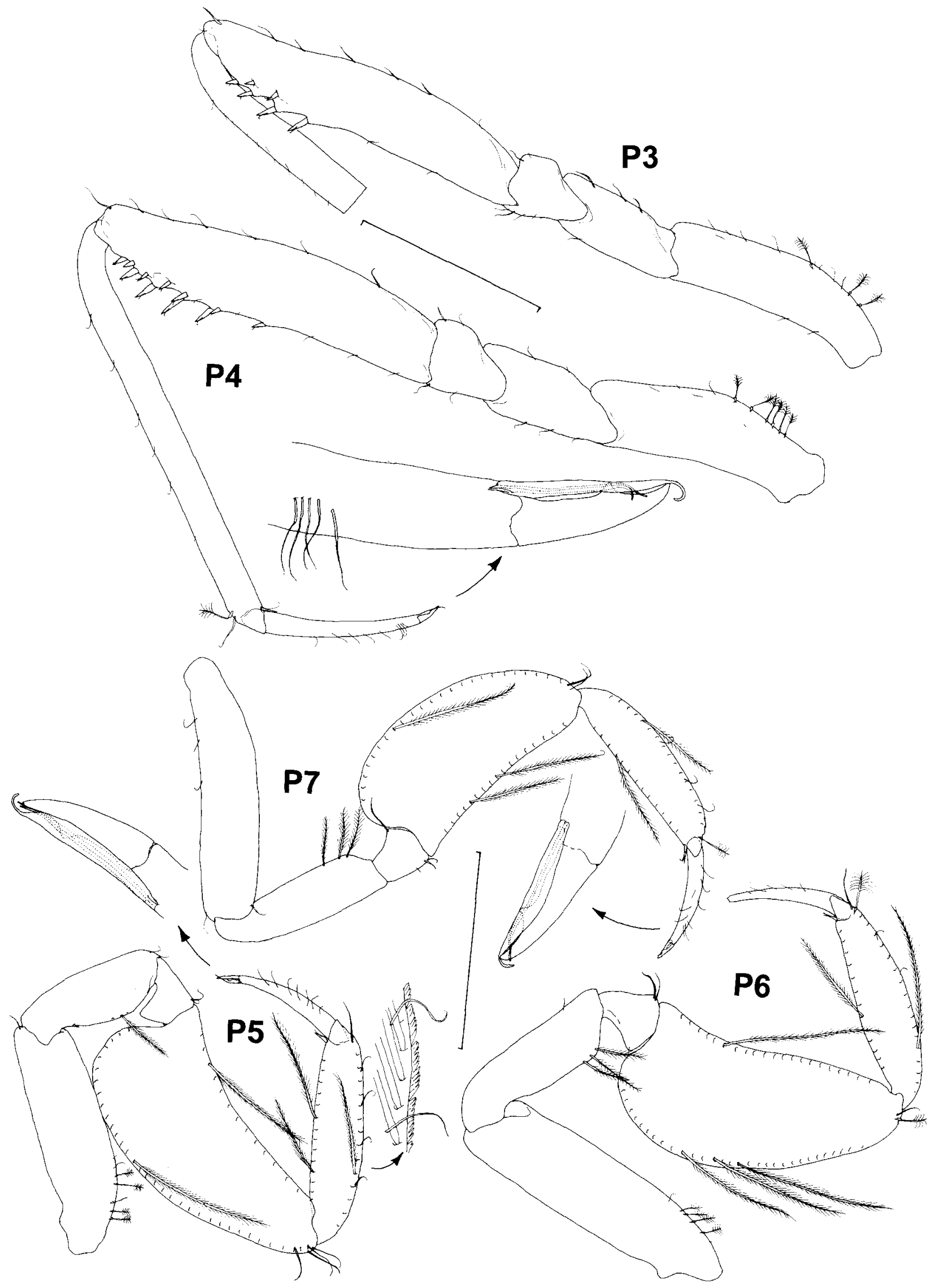

Fig. 9. Storthyngura antarctica sp. nov., female, paratype: pereopods 3-7. 


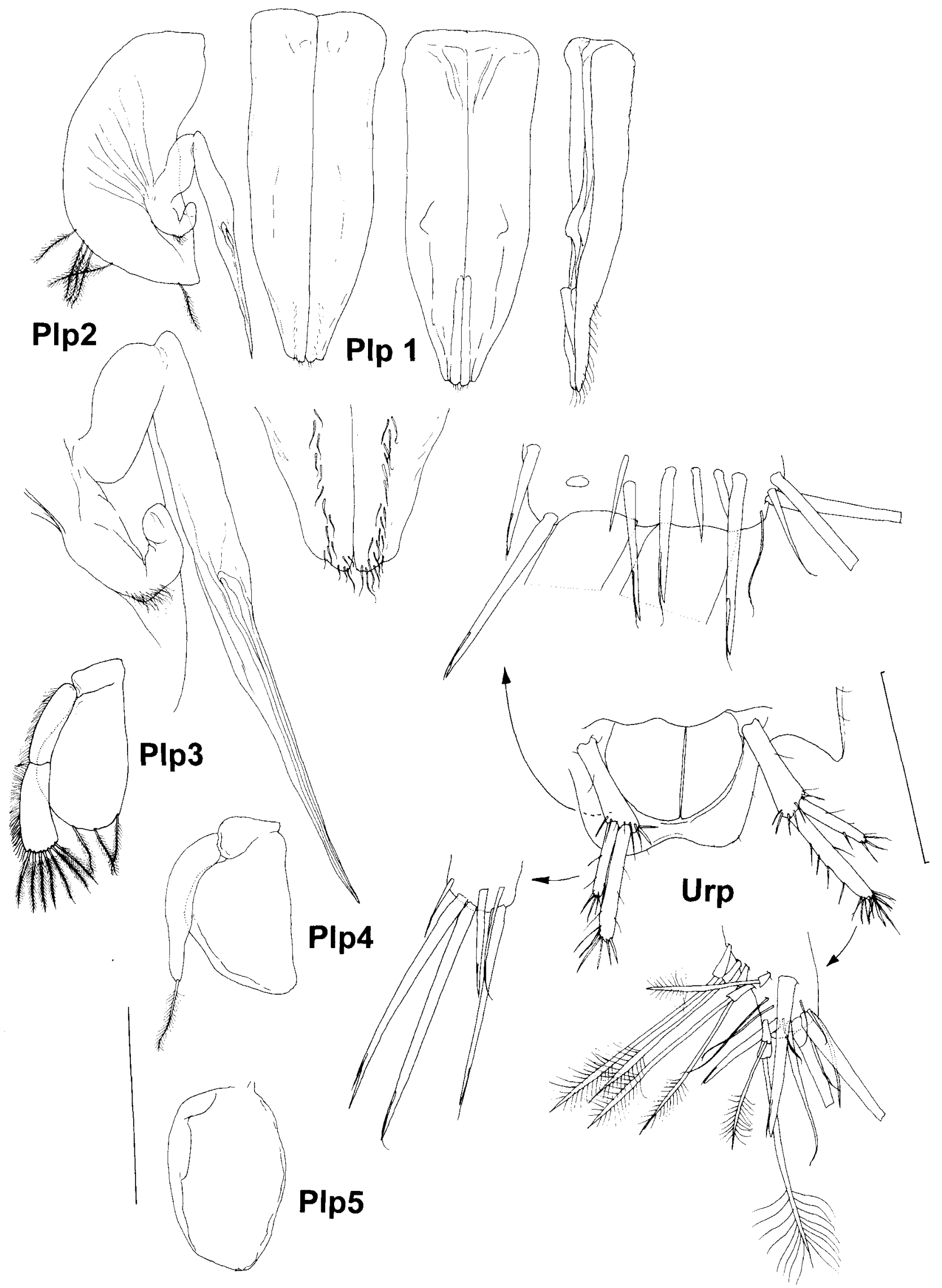

Fig. 10. Storthyngura antarctica sp. nov., male, paratype: pleopods 1-5; male, holotype: uropods. 
Pleopod 3 (Fig. 10) endopod 1.5 times as long as wide, three plumose setae distally, exopod 1.2 times as long as endopod, of two articles subequal in length; basal article 0.25 as wide as endopod, apical article with 7 distal plumose setae and dense row of long hair-like lateral setae.

Pleopod 4 (Fig. 10) endopod 1.5 times as long as broad, exopod 0.2 as wide and 0.95 as long as endopod, with 1 distal plumose seta, margins with fine setae.

Pleopod 5 (Fig. 10) endopod 1.5 times as long as wide.

Uropod (Fig. 10) 0.5 as long as pleotelson. Protopod 3.1 as long as wide, slightly broadening distally, with 12 distal long stout setae. Endopod 6.2 as long as wide, about half as wide and 1.1 times as long as protopod, with 4 medial and 1 lateral small setae, 4 long, strong, unequally bifid setae, 7 long broom and 5 whip setae distally. Exopod 5.4 as long as wide, 0.7 as long as protopod and 0.7 as wide as endopod, with 3 whip and 3 long, strong, unequally bifid setae distally.

Etymology. The epithet refers to the geographic area from which this species was sampled (noun in apposition).

Distribution. Antarctica: Drake Passage off South Shetland Islands, Shackleton Fracture Zone, northwestern Weddell Sea, in a depth of 1019-2894 m.

Remarks. Storthyngura antarctica sp. nov. is similar to S. parka Malyutina \& Wägele, 2001, $S$. longispina sp. nov. and $S$. elegans in the following characters: terminal projection of the pleotelson with a medial notch; pereonite 1 without a dorsomedial projection; short coxa on pereopod 1 ; and pereonite 3 without anterolateral projections. We named these species elegans-group in the Tables 1 and 2. S. antarctica sp. nov. differs from $S$. parka, the most similar species, in having more prominent dorsomedial spines on pereonites 2-4, longer coxal spines, absence of dorsal projections on anterior margin of pereonite 5, paired, not single like in $S$. parka, dorsal tubercles on pereonites 6 and 7, and broader pleotelson with less prominent projections.

In the male from station 41-3-E (Fig. 6) the natasoma is broader than that of the holotype and pereonites 5-7 have more acute and produced anterolateral angles. In the female from 46-7-E (Fig. 6) the distomedial projections of pereonites 2-4 are broad, almost blunt distally and the coxal anterior spines narrower than those in the male holotype.

\section{Storthyngura elegans Vanhöffen, 1914}

Fig. 11

Storthyngura elegans Vanhöffen, 1914: 584, Abb. 114; Monod, 1926: 17, Fig. 9A-G; Malyutina \& Wägele, 2001: 277, Figs 1-6.

Material examined: 129-2-E, 22. 2. 2002, Drake Passage, $59^{\circ} 52.21 \mathrm{~S}, \quad 59^{\circ} 58.75 \mathrm{~W}-59^{\circ} 52.15 \mathrm{~S}, \quad 59^{\circ} 58.03 \mathrm{~W}, \quad 3640-$ $3622 \mathrm{~m}$, female $3.1 \mathrm{~mm}$ long and damaged anterior part of specimen (ZMH, K-40214).

Description of pereopod 3 (not presented in the description of the holotype): Basis with a few small ventral setae and a long dorsal broom seta; ischium more than half as long as basis, with simple small setae; carpus broadest, 1.6 as long as basis, with 3 stout setae on distal ventral third and a few small setae on both margins; propodus half as broad and 1.1 as long as carpus, with stout ventral seta near distal tip and the same distoventral setae; dactylus half as long as propodus, claws damaged.

Remarks. It is the third finding of the species after the records by Vanhöffen and Monod. The two specimens differ from the holotype in having more pronounced dorsal pairs of tubercles on pereonites 6 and 7 and pleotelson.

Distribution. Antarctica: Indian Ocean sector, off Princess Elisabeth Land in a depth of $3423 \mathrm{~m}$; Pacific Ocean sector, in the Bellingshausen Sea in a depth of $400 \mathrm{~m}$; Drake Passage, in a depth of $3622-3640 \mathrm{~m}$.

\section{Storthyngura phyllosoma (Just, 2001) comb. nov.}

Figs $12-16$

Platyprotus phyllosoma Just, 2001: 366, figs 1-8.

Material examined: ANT XV-3, 48-107-E, 06. 02. 1998, $73^{\circ} 34.77 \mathrm{~S}, 22^{\circ} 38.29 \mathrm{~W}-73^{\circ} 34.92 \mathrm{~S}, 22^{\circ} 38.89 \mathrm{~W}$ depth $938 \mathrm{~m}$, female $4.1 \mathrm{~mm}$ long (ZMH, K-40215)

Re marks. We herewith present the drawings of the specimens examined for comparison (see generic remarks and Table 2).

S. phyllosoma differs from other Storthyngura species in having the broadest natasoma, where pleotelson is wider or subequal in width to pereonites 5-7, the narrowest pereopods $5-7$ and long, distally widened marginal setae on terminal article of mandibular palp. S. phyllosoma belongs to the species of magnispinis-group (Tables 1 and 2) in bearing a rounded terminal projection of pleotelson without medial notch; pereonite 1 with dorsomedial projection; long coxa of pereopod 1; pereonite 3 with anterolateral spines. S. phyllosoma and S. kussakini from this group 


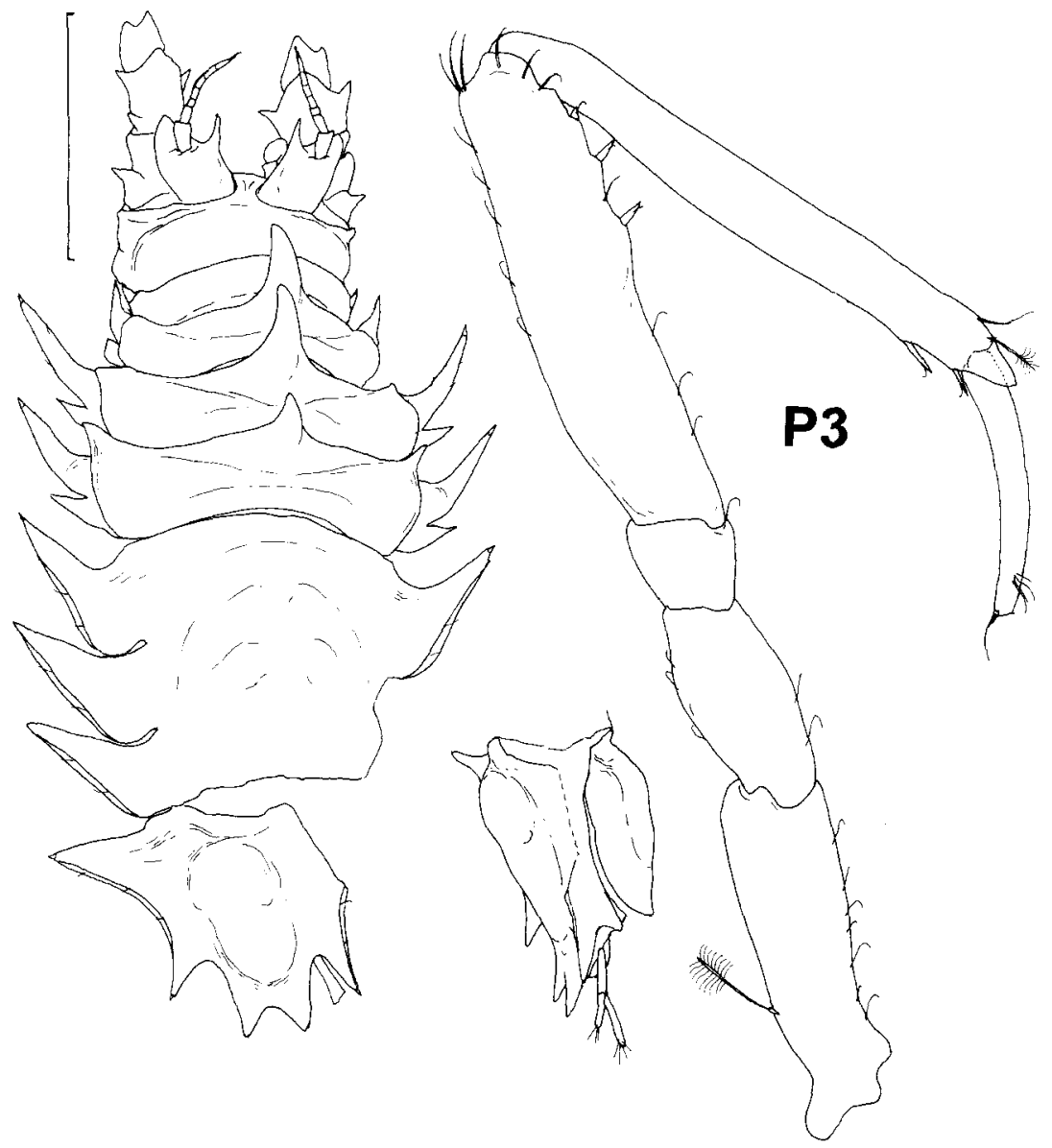

Fig. 11. Storthyngura elegans Vanhöffen, 1914, female: a, dorsal view; b, pleotelson, lateral view; pereopod 3 . share a narrow carpus of pereopods 5-7. The shape of natasoma of $S$. phyllosoma, almost without lateral projections resembles that of $S$. antarctica sp. nov. from the elegans-group (Fig. 20). The dorsal surface of the pleotelson of S. phyllosoma is similar to all other species of the elegans-group with a pair of tubercles in the middle behind a rounded anterior elevation.

Distribution. Antarctica: Indian Ocean sector, off Enderby Land, in a depth of $540 \mathrm{~m}$; Atlantic sector, Weddell Sea, in a depth of $938 \mathrm{~m}$.

\section{Storthyngura kussakini Brandt \& Malyutina, 2002}

Figs $17-18$

Storthyngura kussakini Brandt \& Malyutina, 2002: 98, Figs 1-6.

Material examined. 133-3-E, 7. 3. 2002, Drake Passage off South Shetland Islands, $65^{\circ} 20.17 \mathrm{~S}, \quad 54^{\circ} 14.30 \mathrm{~W}-$ $65^{\circ} 20.05 \mathrm{~S}, 54^{\circ} 14.46 \mathrm{~W}, 1021-1019 \mathrm{~m}$, female $10.8 \mathrm{~mm}$ long (ZMH, K-40215).

Because the type material included only males, we present differences of the female from the males.

Females are larger than males, body 1.8 times as long as wide. Anterolateral margins of pere- onites 5-7 and pleotelson acute, dorsal spines on natasome more slender. Pleotelson preanal ridge short, weakly bent posteriorly.

Antenna 1 (Fig. 17) article 11.5 times as long as wide, lateral margin serrated, with plumose distal seta, medial spine small, 0.2 times as long as article, stout spine-like seta distally on spine and dorsally behind article 2 insertion, set of small dorsal plumose setae medially; article 2 shorter than distolateral lobe of article 1 , with 2 plumose setae distally; article 31.5 times, article 40.3 times as long and half as wide as article 2; first flagellar article longest, following 21 articles decreasing in length distally, with aestetascs. Flagellum in female consists only slightly less articles and almost does not differ from that in male (Fig. 17).

Pereopod 3-4 (Fig. 18) more slender, than in male (Fig. 18), propodi with pair of dorsal strong setae, absent in male, ventral spine-like setae on propodus shorter, situated only on distal half.

Pereopod 5 (Fig. 18) with carpus and propodus slender, but carpus broader than that in male (Fig. 35, compare Brandt \& Malyutina, 2002: Fig. 5), both margins with dense rows of plumose setae (in male sparse natatory setae are only on dorsal margin), dorsal margin of propodus serrated, with additional whip setae. 

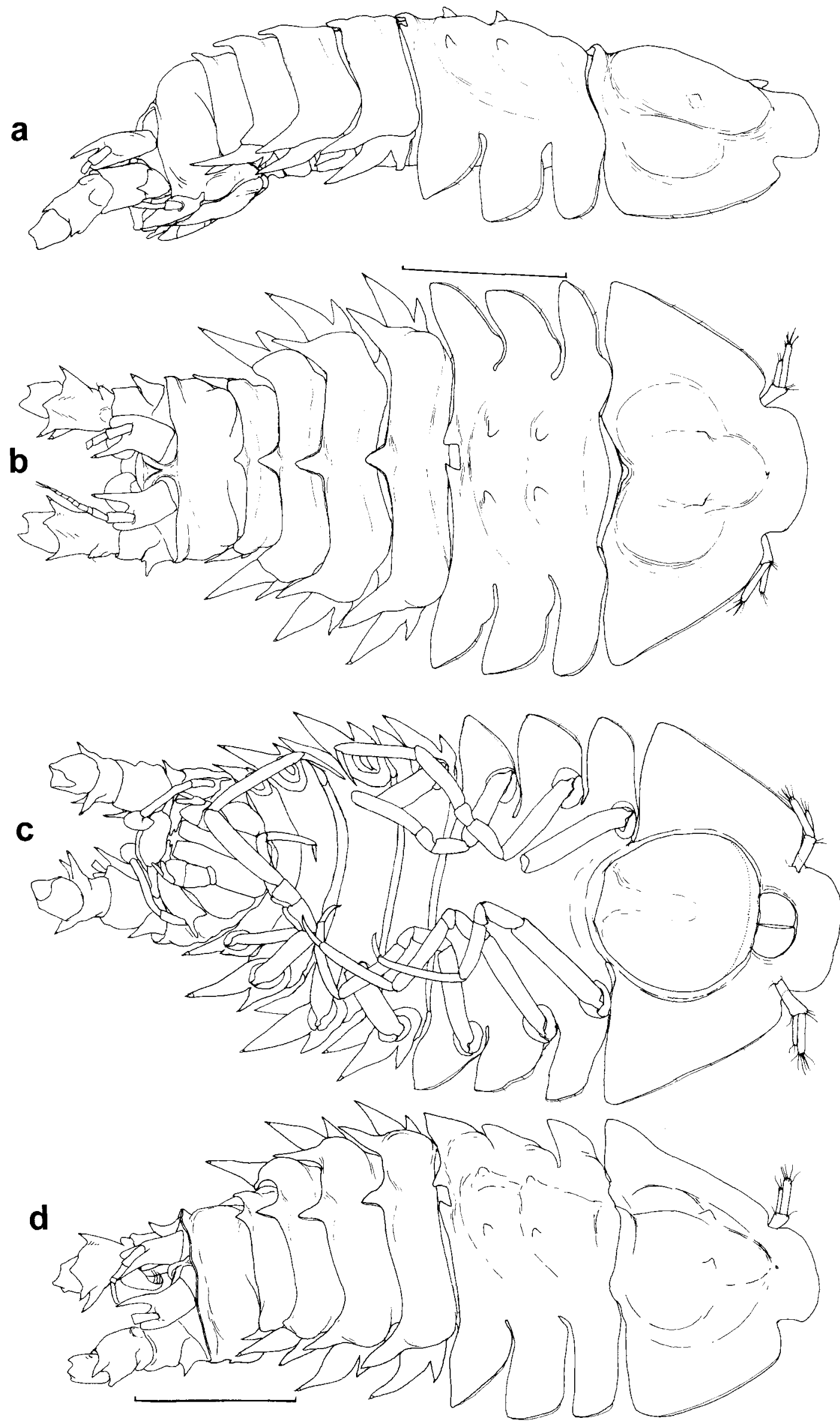

Fig. 12. Storthyngura phyllosoma (Just, 2001), female: a, lateral body view; $\mathbf{b}$, dorsal view; $\mathbf{c}$ ventral view; d, oblique lateral view. 


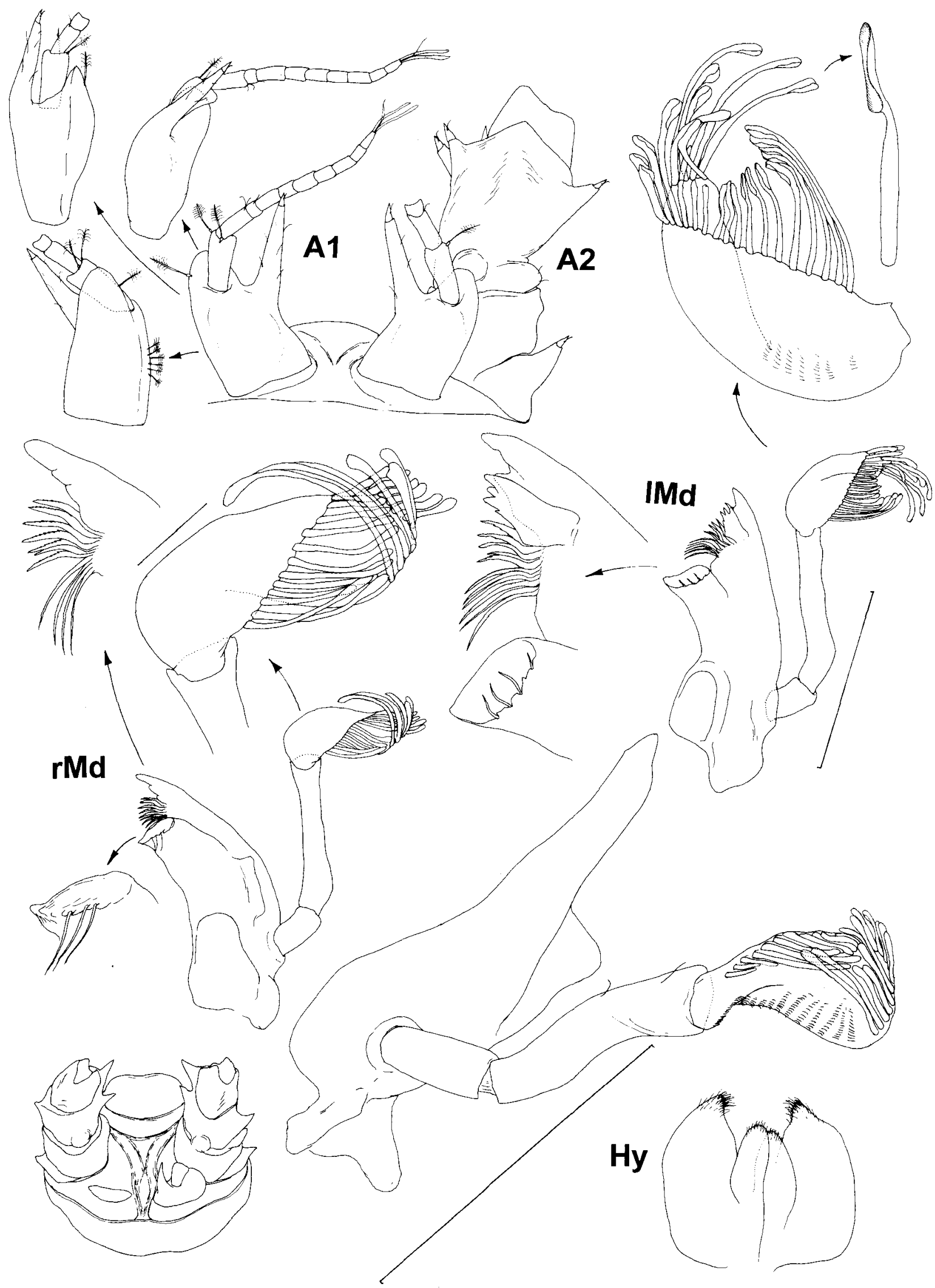

Fig. 13. Storthyngura phyllosoma (Just, 2001), female: a, head, frontal view; antennae and mouthparts. 


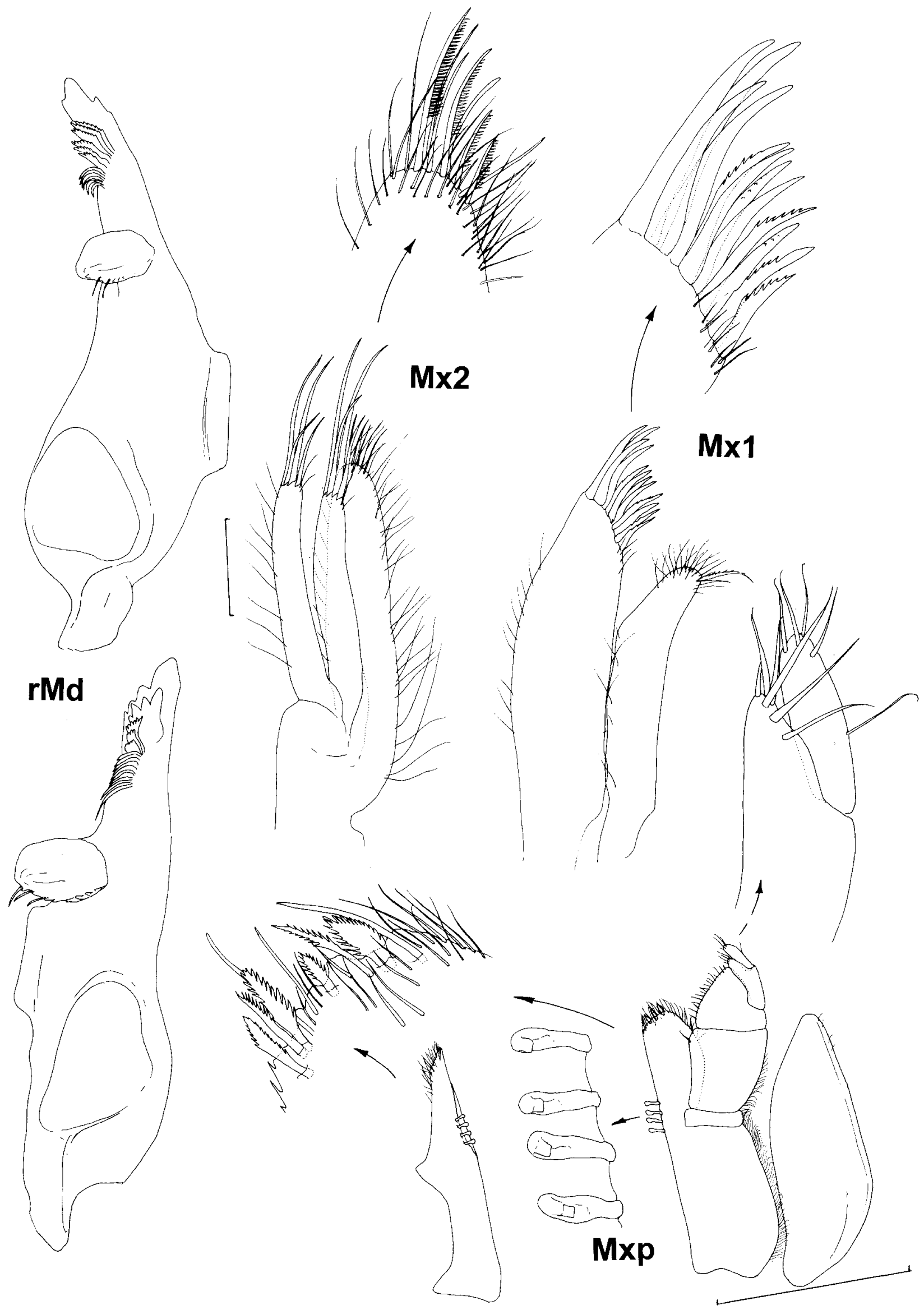

Fig. 14. Storthyngura phyllosoma (Just, 2001), female: mouthparts. 


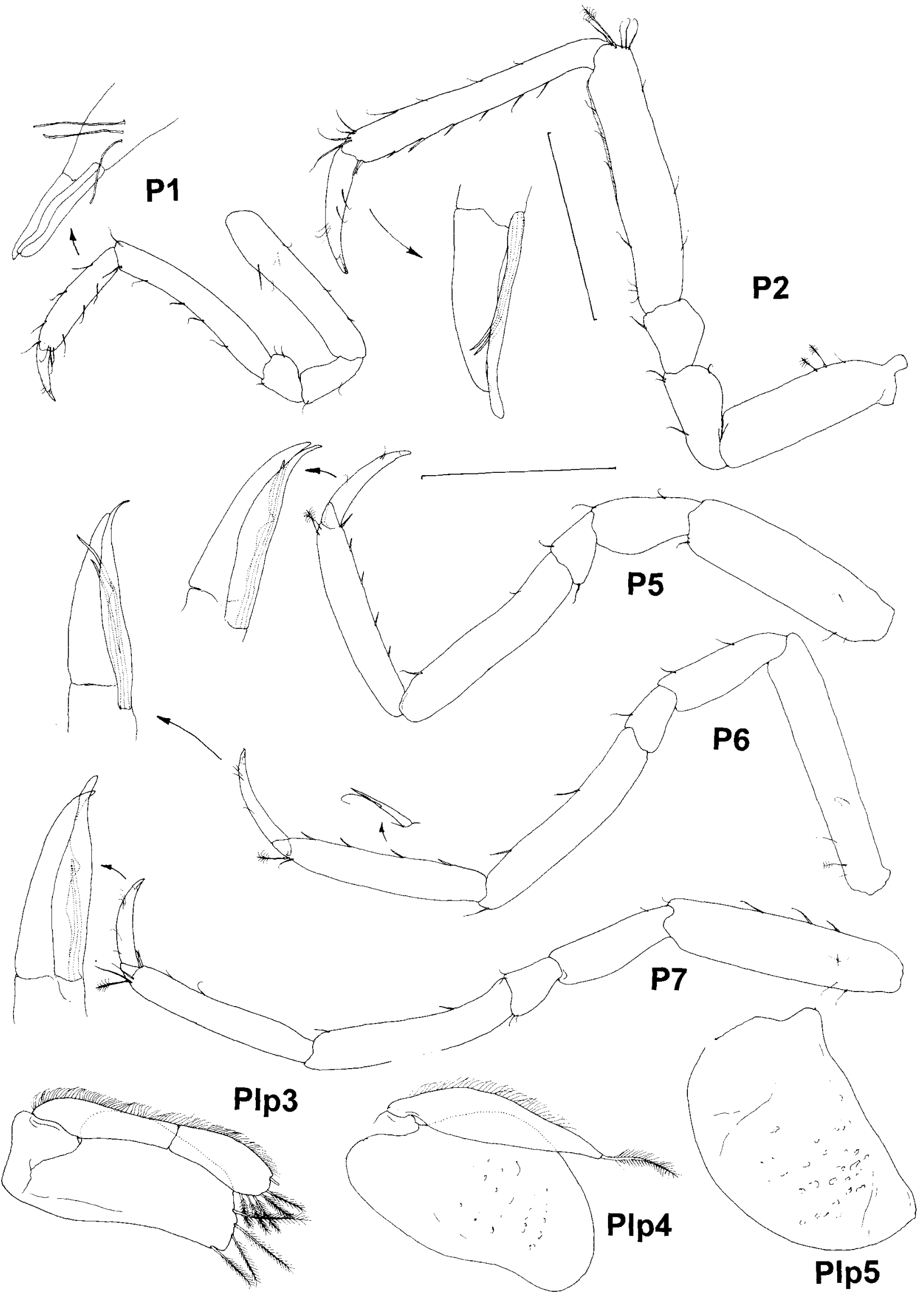

Fig. 15. Storthyngura phyllosoma (Just, 2001), female: pereopods 1, 2, 5-7 and pleopods 3-5. 


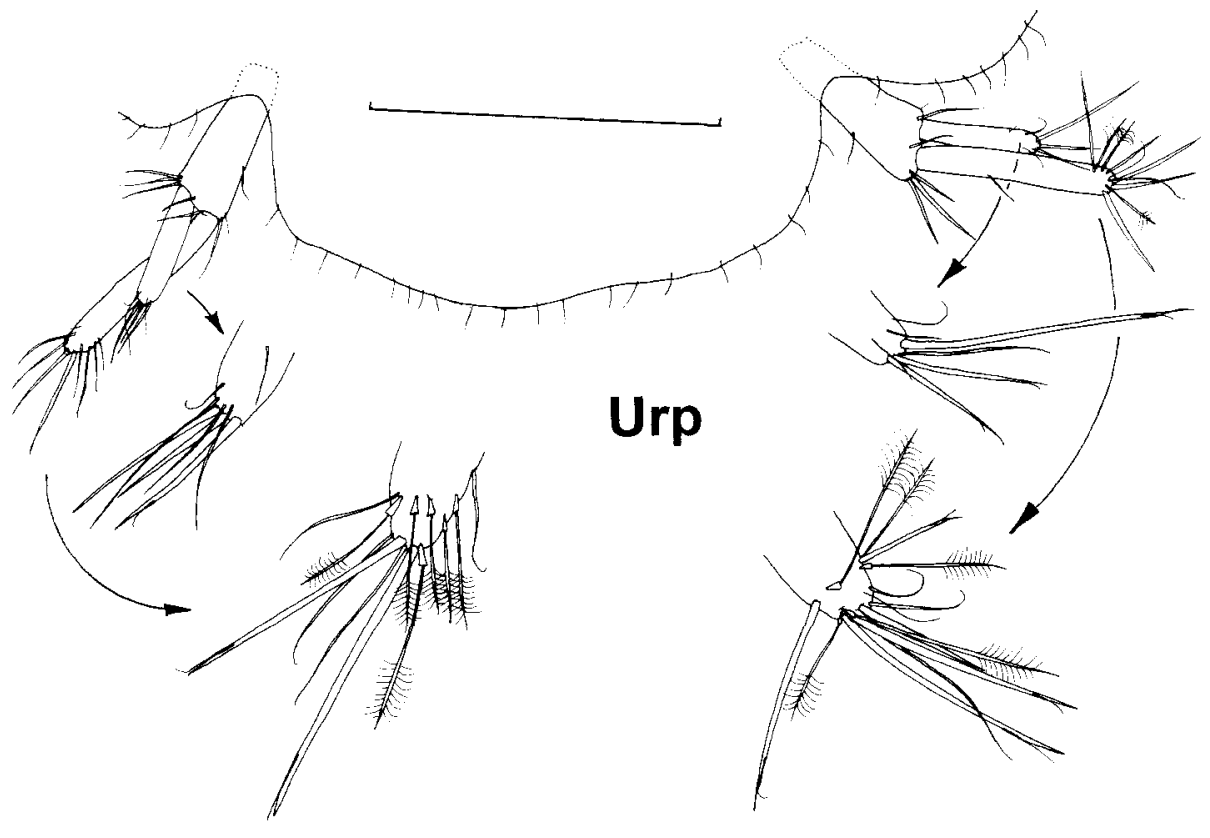

Fig. 16. Storthyngura phyllosoma (Just, 2001), female: posterior margin of pleotelson with uropods (scale bar $0.3 \mathrm{~mm}$ ).
Male pleopod 1 (Fig. 18) bent ventrally, with thick, serrated longitudinal keels on ventral basal half.

Distribution. Antarctica: Atlantic sector, Weddell Sea, off Kapp Norwegia, in a depth of 181-182 m; Drake Passage off South Shetland Islands, in a depth of $1019-1021 \mathrm{~m}$.

\section{Storthyngura snanoi Menzies, 1962}

Fig. 19

Storthyngura snanoi Menzies, 1962: 149, Fig. 40C-E.

Material examined. Female $3.2 \mathrm{~mm}$ long, holotype (AMNH, No I-145), L.G.O. Biotrawl N 85, Vema-15-10, 7 Nov. $1958,4071 \mathrm{~m}, 14^{\circ} 05^{\prime} \mathrm{N}, 75^{\circ} 25^{\prime} \mathrm{W}$, central part of Colombia Abyssal Plain, SBT.

Description of the holotype. Body (Fig. 19) 2.4 times as long as pereonite 5 , height 0.2 of length. Head 0.6 times as long as wide; interantennular distance 0.2 times as wide as head and 0.7 as wide as antenna 1 basis; frons slightly concave medially, frontal arch low, with weak lateral ridges.

Pereonites 1-4 subequal in length, anterolateral corners of pereonite 1 rounded, pereonites 2-4 with anterolateral pointed projections, increasing in length from 2 to 4 ; anterior margin of pereonites $1-4$ with frontally directed dorsomedial acute projection, about half as long as pereonite. Coxal anterior spine of pereopod 1 as long as those of pereopods 2-4; all coxal spines with distal spine-like stout seta and small thin setules around.
Natasoma 1.2 times as long as anterior part of body. Pereonite 5 longest, pereonite 7 not fully developed; anterolateral projections of pereonites tapering, directed anteriorly. Anterior margin of pereonite 5 with 2 small acute dorsomedial projections; pereonites 6 and 7 with pair of low dorsal elevations.

Pleotelson as long as wide anteriorly and 0.7 times as long as wide in middle part; lateral spine-like projections well pronounced, slender; anterolateral ones slightly larger than posterolateral, lateral margins in between convex, rounded; terminal apex rounded, twice as wide as long, 0.2 times as long as pleotelson; dorsal surface with 2 small tubercles on level of posterolateral projections; preanal ventral ridge slightly prominent.

All body margins with sparse minute setae.

Antenna 1 (Fig. 19) about 0.2 times as long as body, 8 articles; article 11.9 times as long as wide, medial spine 0.15 as long as article; article 2 slightly longer than distolateral lobe of article $1,0.3$ times as long as article 1 ; articles 3-6 1.2, $0.25,0.9,0.6$ times as long as article 2 respectively; articles 3-8 almost half as wide as article 2 , terminal article with 2 aesthetascs, 1 broom and 1 small simple setae.

Antenna 2 (Fig. 19) broken, only 4 basal articles present in this specimen. Article 1 with distolateral minute spine-like projection; article 3 almost twice as long as article 2 dorsally, medial projection at least twice as long as lateral spine, lateral margin with small setae.

Mandibles, maxilla 1 and maxilla 2 not studied. 

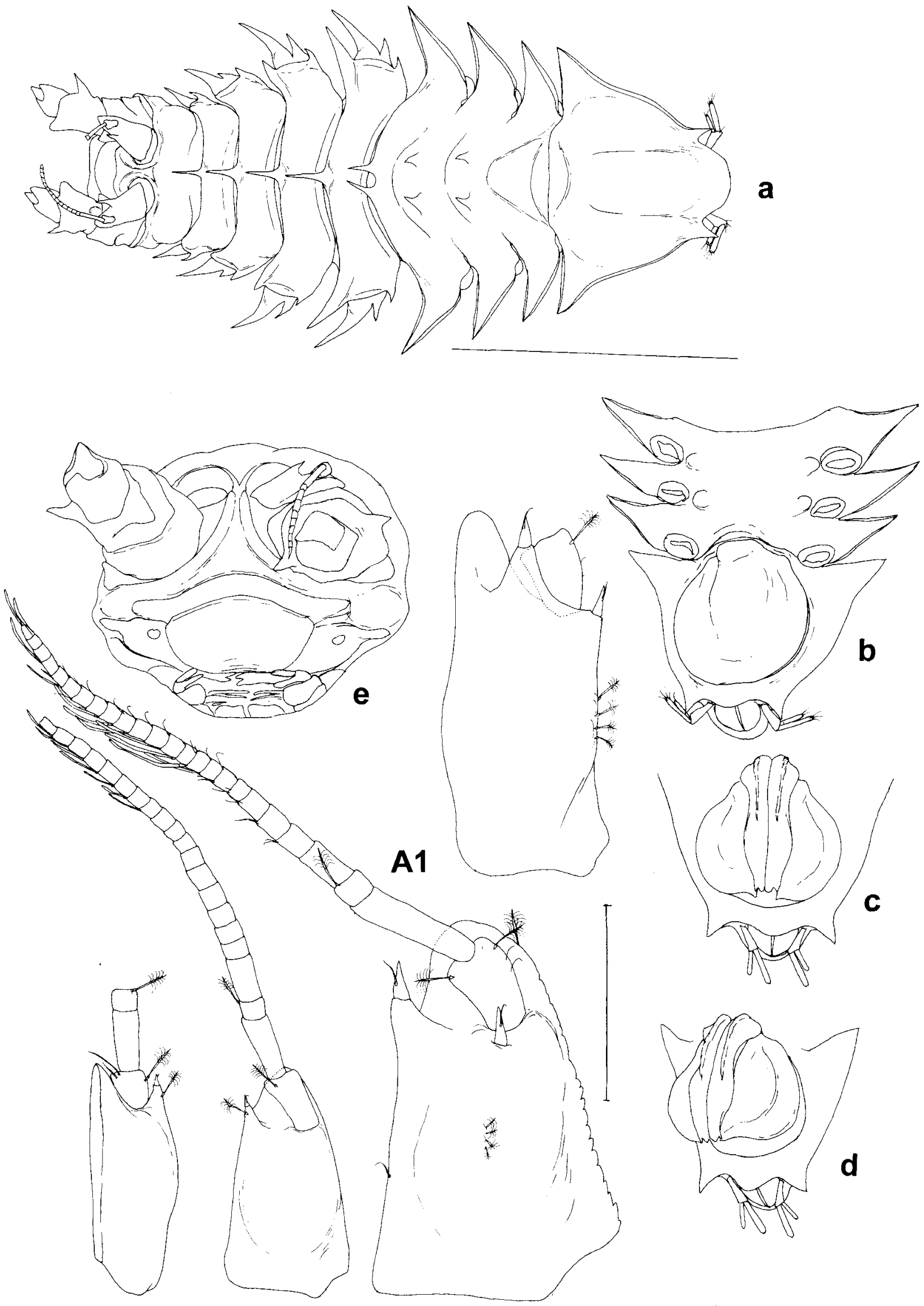

Fig. 17. Storthyngura kussakini Brandt \& Malyutina, 2002, female: a, dorsal total view, b, natasoma, ventral view; c, d, pleotelson of male, paratype: c, ventral view, d, oblique lateral view; e, head, frontal view; antenna 1 of female and male, paratype. 


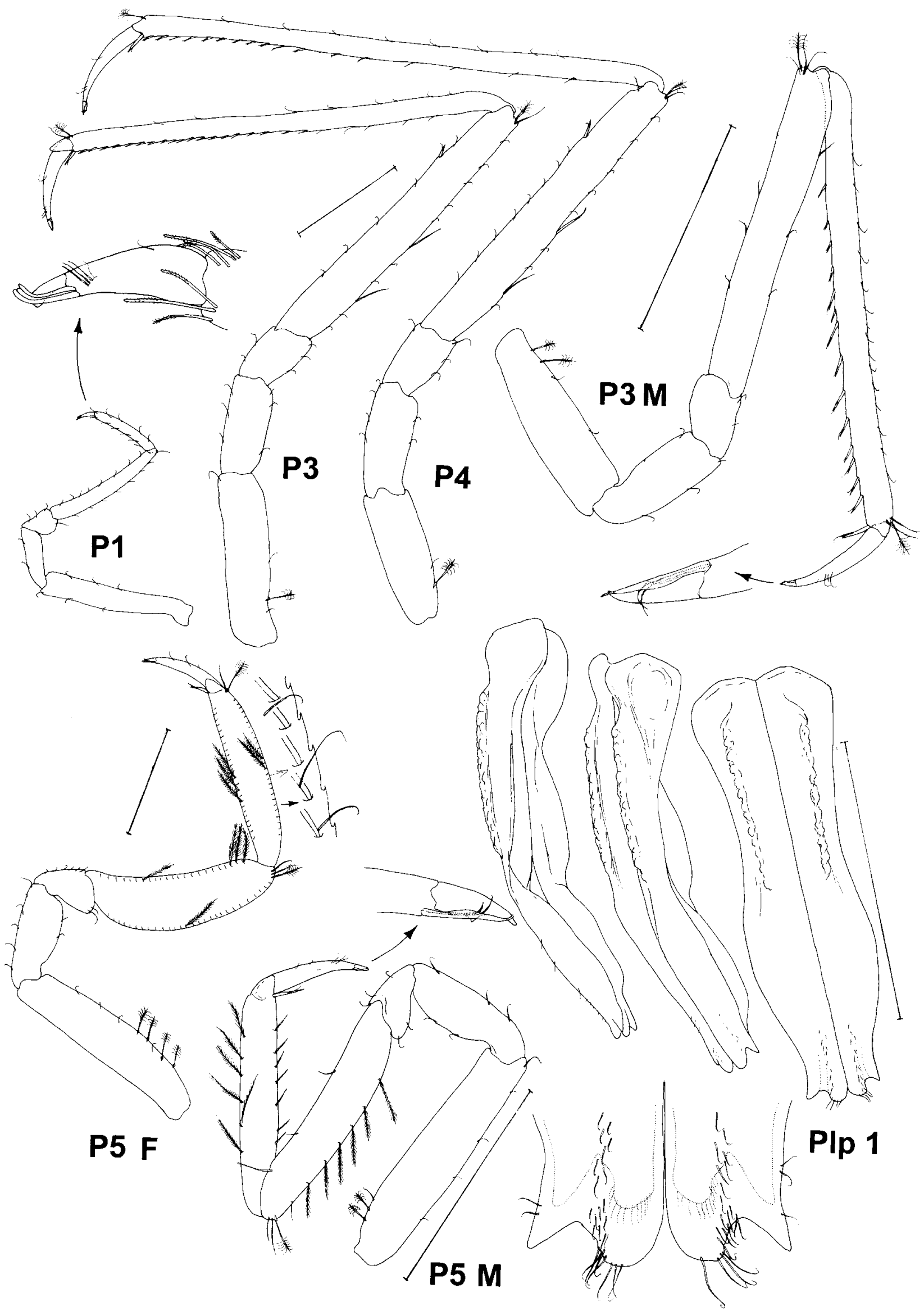

Fig. 18. Storthyngura kussakini Brandt \& Malyutina, 2002, female: pereopods 1, 3-5 (scale bar 0.3 mm); male, paratype: pereopod 3,5 and pleopod 1. 
a
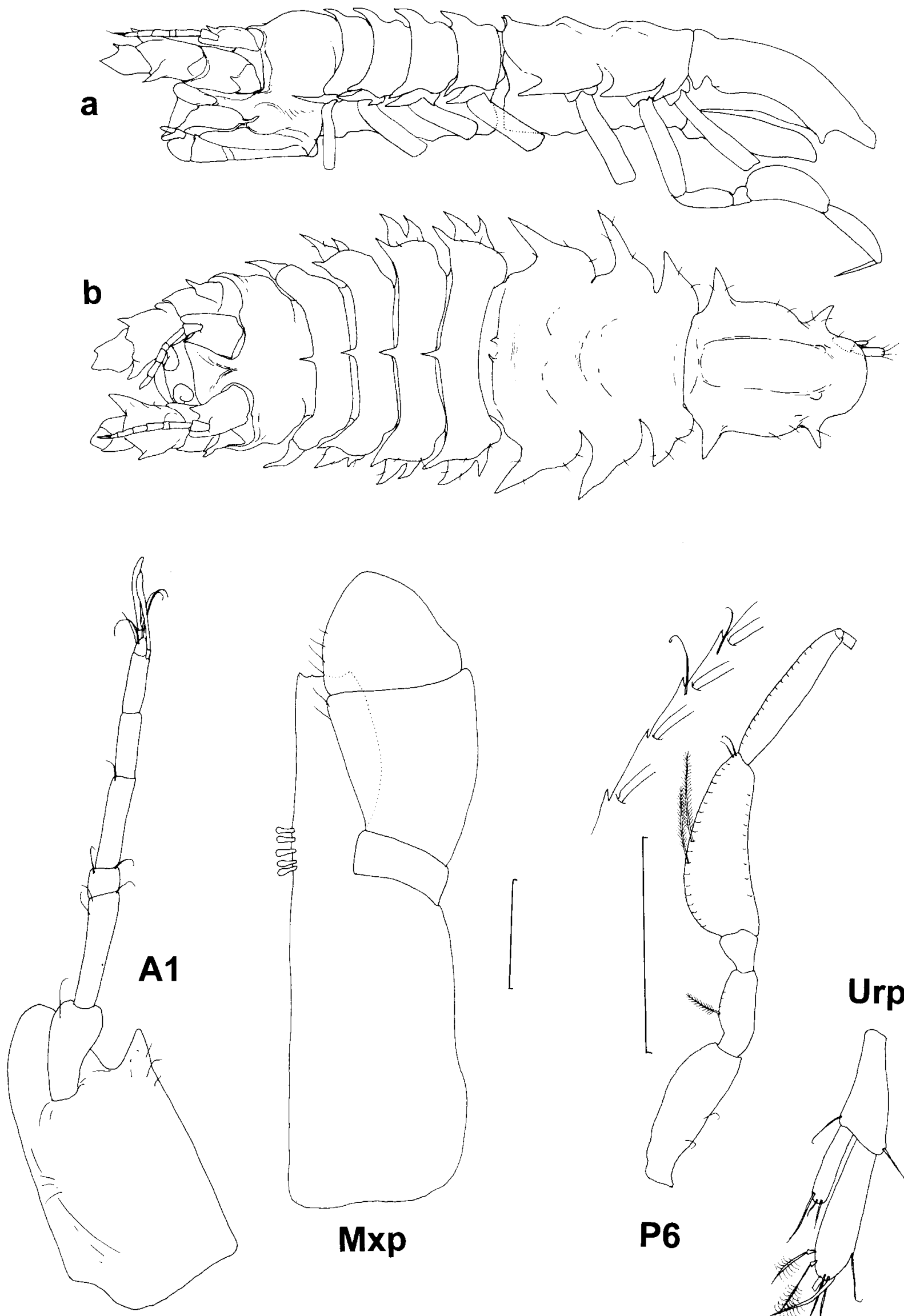

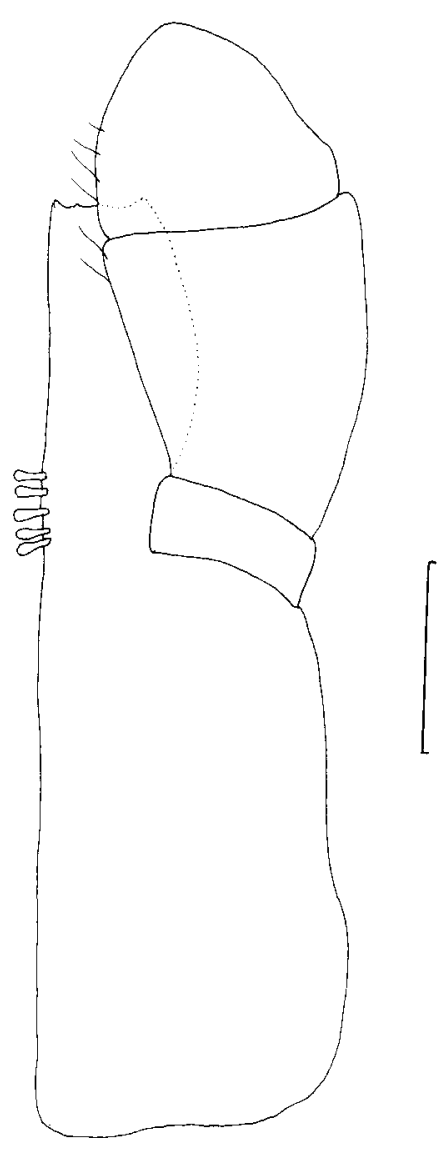

Mxp

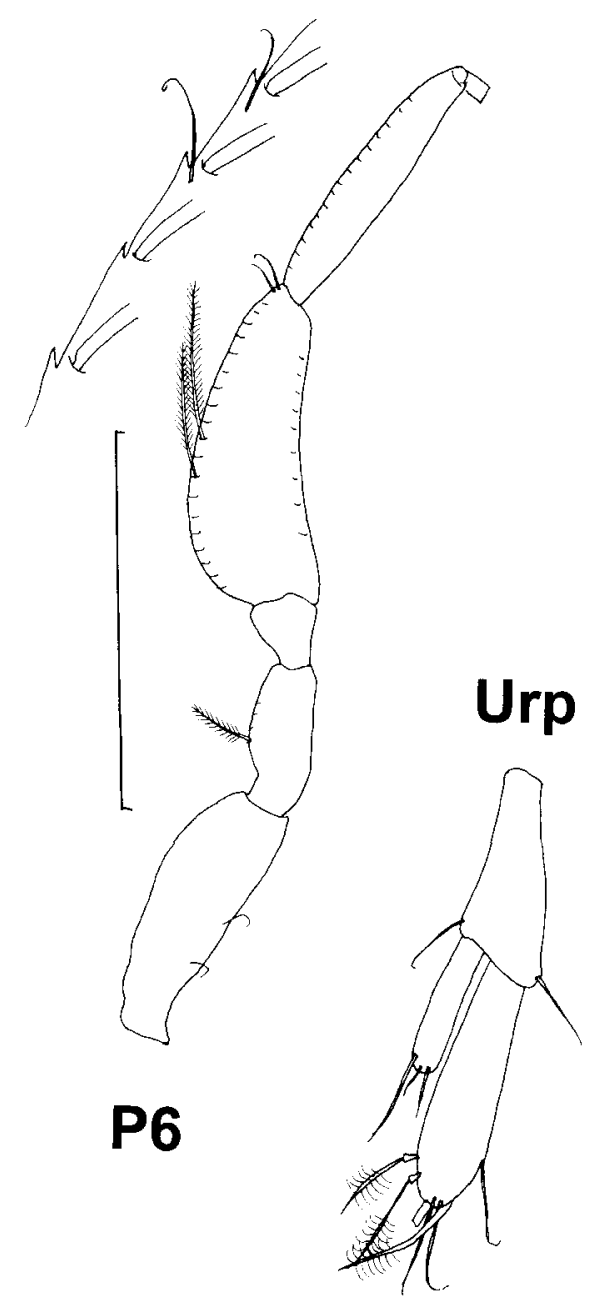

Fig. 19. Storthyngura snanoi Menzies, 1962, female, holotype: a, total lateral view; b, dorsal view; antenna 1, maxilliped (scale bar $0.3 \mathrm{~mm}$ ), pereopod 6, uropod. 


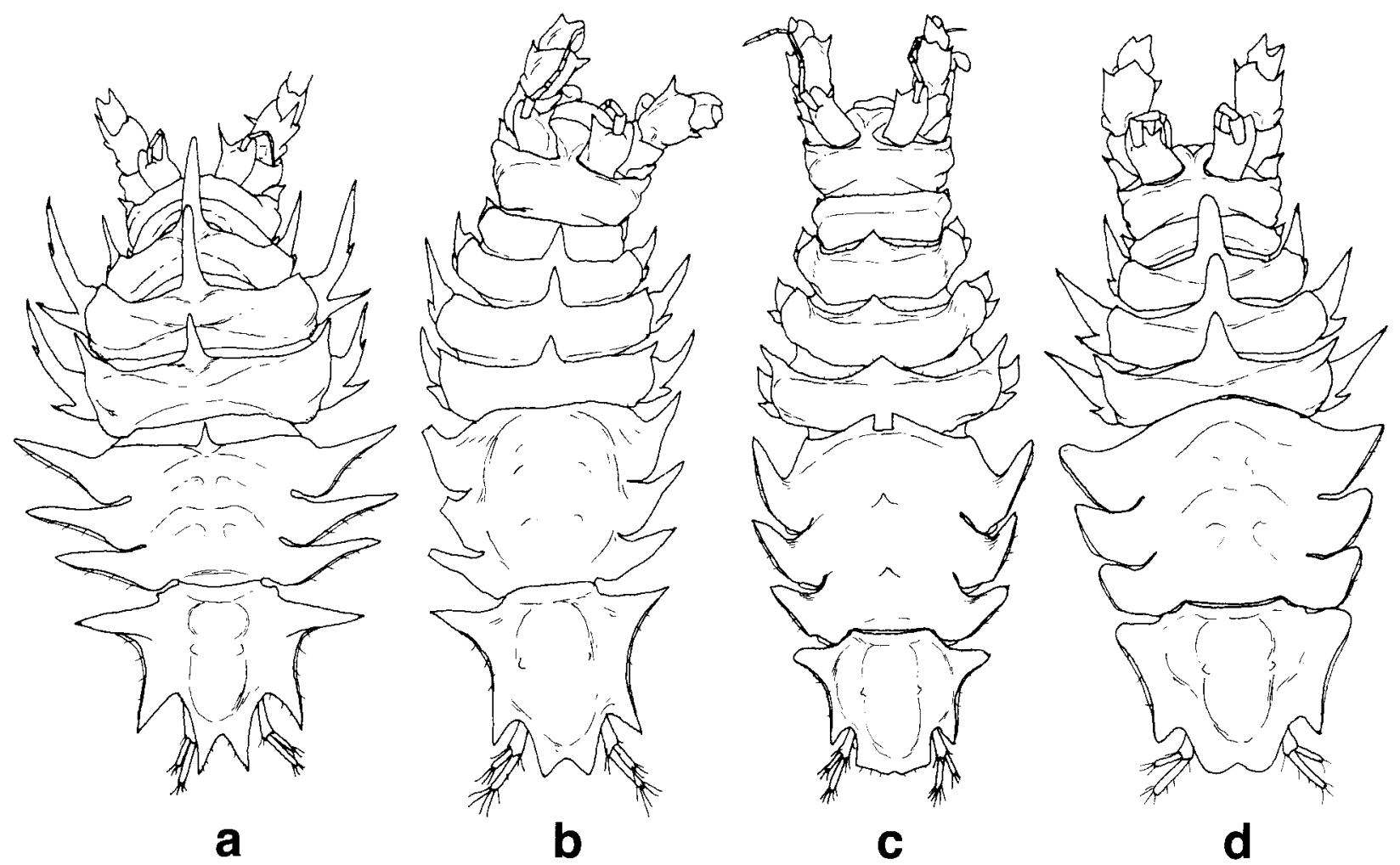

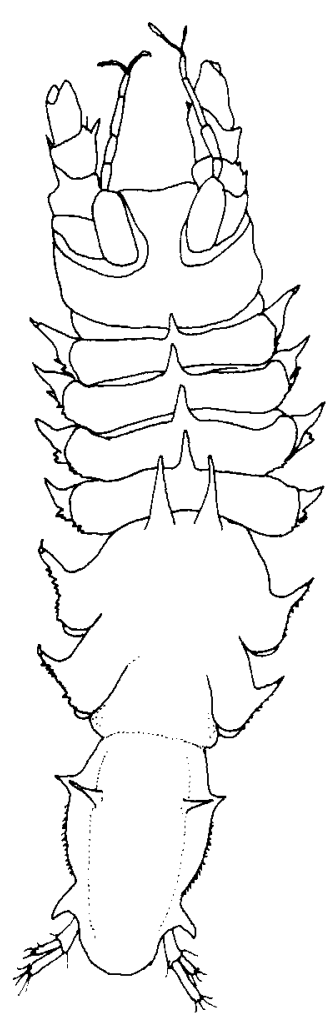

e

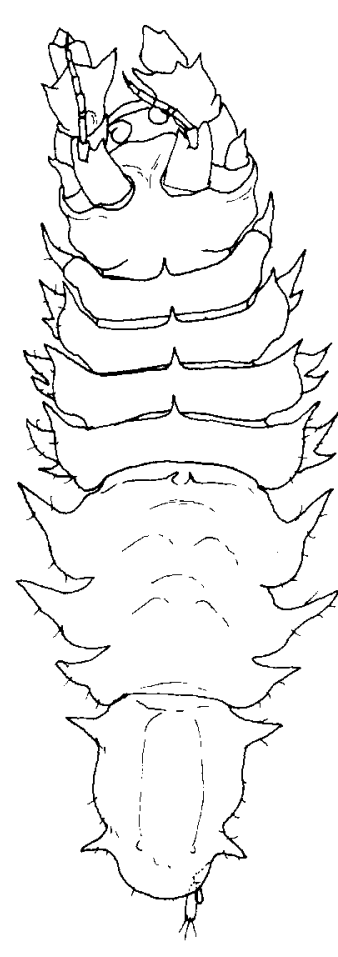

f

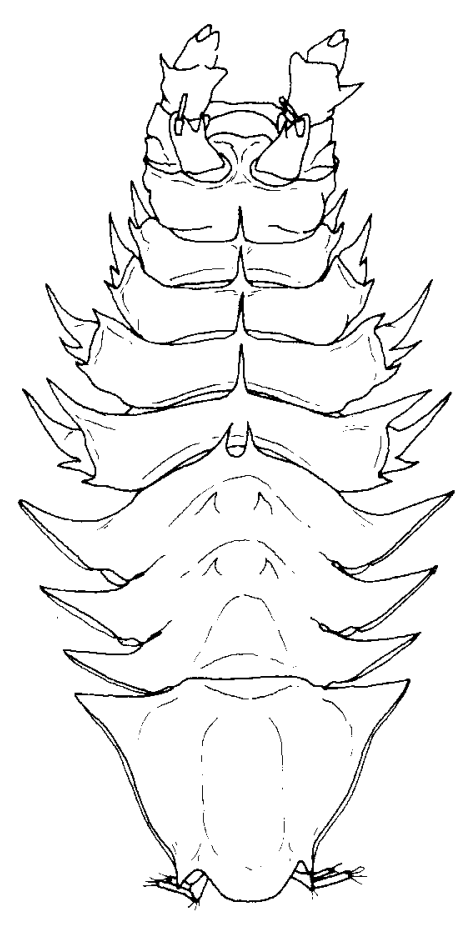

g

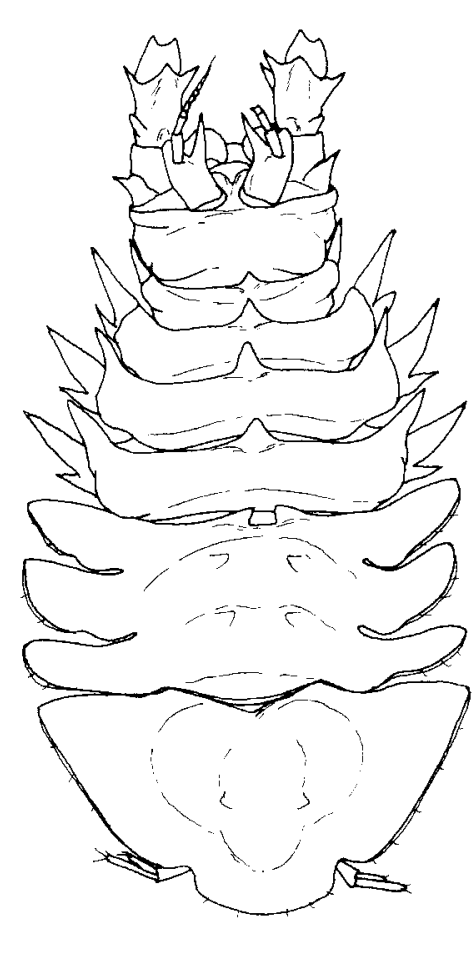

h

Fig. 20. Dorsal views of some species of Storthyngura: a, S. longispina sp. nov.; b, S. elegans; c, S. parka; d, S. antarctic sp. nov.; e, S. octospinosalis; f, S. snanoi; g, S. kussakini; and h, S. phyllosoma. (b, c, from Malyutina \& Wägele, 2001; e, from Menzies $\&$ George, 1972). 
Maxilliped (Fig. 19) endite half as wide as basis, with 5 coupling hooks; palp article 2 medial margin straight, 0.7 times as long as lateral margin; article 3 medial margin slightly convex; articles 4 and 5 and epipod broken off.

All pereopod bases subequal in length, slightly longer in pereopods 5-7.

Pereopod 6 (Fig. 19) carpus visible broader than and subequal in length to basis; propodus 0.9 times as long as carpus, both articles with plumose marginal setae; ischium half as long as basis; dactylus broken off.

Operculum rounded, slightly longer than wide; keel low, narrow, distal margin with plumose setae.

Pleopods 3-5 not studied.

Uropod (Fig. 19) 0.3 times as long as pleotelson. Protopod 2.5 times as long as wide, broadening distally, with 2 distal setae; endopod 3.6 as long as wide, more than half as wide and 1.2 as long as protopod, with 2 or 3 strong, unequally bifid setae, 3 or 4 broom and 3 whip setae distally; exopod 5.4 times as long as wide, 0.6 times as long and 0.7 as wide as endopod, exopod 2.8 times as wide as protopod, with 3 whip and 3 long, strong, unequally bifid setae distally.

Remarks. We classify $S$. snanoi to the magnispinis-group (Tables 1 and 2) because the terminal projection on the pleotelson is without a medial notch; pereonite 1 bears a dorsomedial projection; pereopod 1 coxa is long; and pereonite 3 bears anterolateral spines. $S$. snanoi is most similar to S. vemae Menzies, 1962, S. truncata and S. magnispinis Richardson, 1908. In all these species the pleotelson is elongate, with protruding small lateral spines and convex margins in between these spines. S. octospinosalis Menzies \& George, 1972 has similar shape of the pleotelson, but with a pair of long acute dorsal spines on pleotelson. Authors have illustrated rounded anterolateral angles of all ambulosomal pereonites, but we are not sure if this is correct.

Distribution. Western Atlantic: Caribbean Sea, in a depth of $4071 \mathrm{~m}$.

\section{Acknowledgements}

The project was undertaken with financial support of the Deutsche Forschungsgemeinschaft (436 RUS 17/20/02; $\mathrm{Br}$ $1121 / 20-1)$. The authors are very grateful to the crew of the RV Polarstern during the expeditions ANT XIX3-4, ANDEEP I \& II), to Mrs E. Borda from the American Museum of Natural History, New York, USA for the loan of the holotype of Storthyngura snanoi. Ms Anna Ushakova kindly inked part of the drawings. Dr. Niel Bruce (NIWA. Wellington, New Zealand) made many useful comments and corrections, which improved the manuscript considerably. We are very grateful for their help. This is ANDEEP publication 1 .

\section{References}

Birstein, Ya. A. 1969. Crustacea Isopoda from the Romanche Trench. - Bulleten' Moscovskogo Obshchestva Ispytatelei Prirody. Otdel biologicheskii 3: 50-69 (in Russ.).

Brandt, A. \& Barthel, D. 1995. An improved supra- and epibenthic sledge for catching Peracarida (Crustacea, Malacostraca). - Ophelia 43 (1): 15-23.

Brandt, A. \& Malyutina, M. V. 2002. Storthyngura kussakini sp. nov. From the Southern Ocean. - Mitt. Mus. Nat.kd. Berl., Zool. Reihe 78 (1): 97-107.

George, R. Y. \& Menzies, R. J. 1968. Distribution and probable origin of the species in the deep-sea isopod genus Storthyngura. - Crustacea 15: 171-187.

Just, J. 2001 Platyprotus phyllosoma, gen. nov., sp. nov., from Enderby Land, Antarctica, an unusual munnopsidid without natatory pereopods (Crustacea: Isopoda: Asellota). Memoirs of Museum Victoria 58 (2): 335-345.

Kussakin O. G. 2003. Morskye I solonovatovodnye ravnonogie rakoobrasnye (Isopoda) cholodnix I umerennix vod severnogo polushariya (in Russ.) T. III Asellota. Part 3 Munnopsidae, pp. 1-380.

Malyutina, M. V. 1999. Storthyngurella, new genus of Munnopsidae (Crustacea: Isopoda), with descriptions of three new species from deep-sea basins of the Southern Hemisphere. - Memoirs of Museum Victoria 57 (2): 267-285.

- 2003. Revision of the genus Storthyngura Vanhöffen, 1914 (Crustacea, Isopods, Munnopsididae) with descriptions of three new genera and four new species from the deep South Atlantic. - Org. Divers. Evol. 3: 245-252, Electr. Suppl. 13: 1-701 (2003).

Malyutina, M. V. \& Wägele J. W. 2001. Redescription of Storthyngura elegans Vanhöffen, 1914 and description of a new deep-sea species of Storthyngura from the Peru Basin. - Mitt. Mus. Nat.kd. Berl., Zool. Reihe 77 (2): 277-295.

Menzies, R. J. 1962. The isopods of abyssal depths in the Atlantic Ocean. - Vema Research Series 1: 79-206.

Menzies, R. J. \& George R. Y. 1972. Isopod Crustacea of the Peru-Chile Trench - Anton Bruun Report 9: 9.3-9.124.

Vanhöffen E. 1914. Die Isopoden der Deutsche Südpolar Expedition 20, Zool. 7: 449-598. 